\title{
On the use of CPTs in stratigraphy: recent observations and some illustrative cases
}

\author{
Marco SCHILTZ \\ Samsuffit BVBA, Eggelstraat 8, 2530 Boechout,Belgium; marco@samsuffit.be.
}

ABSTRACT. During processing and interpretation of about 200 Cone Penetration Tests (CPT) with electrical cones in a limited area of $60 \mathrm{~km}^{2}$ in NE Belgium, a close analogy was observed between the vertical trend and signature of two CPT derived parameters (normalized soil behavior index $\mathrm{I}_{\mathrm{c}}$ and hydraulic conductivity $\mathrm{k}_{\mathrm{SBTn}}$ ) and borehole gamma ray (GR) measurements. This close analogy could be repeatably observed on five locations with a CPT executed along a cored and logged borehole.

Using this feature proves to be a considerably help for stratigraphic interpretation, especially for sandy units displaying low lithological contrast. Lithostratigraphic units and their boundaries are determined by the specific log response patterns of these CPT derived parameters $\left(\mathrm{k}_{\mathrm{SBTn}}\right.$ and/or $\left.\mathrm{I}_{\mathrm{c}}\right)$. These log responses prove to be more consistent and better to correlate than for the classical parameters (cone resistance qc and friction ratio Rf).

This paper describes the case of a Neogene setting in the NE of Belgium where this feature was first observed. An informal stratigraphy based on CPT log signal is proposed for the geological units for the research area. Some other cases are briefly described to illustrate the usability of this feature for other geological settings or issues.

KEYWORDS: Neogene, cone penetration testing, borehole logging.

\section{Introduction}

During 2008 and 2010 the National Institute for Radioactive Waste and Enriched Fissile Materials (ONDRAF/NIRAS) organized two comprehensive field test campaigns (Wouters \& Schiltz, 2013) situated in the NE of Flanders. The subject of these field campaigns was a hydrogeological safety study for a disposal facility for low radioactive waste storage. This investigation area is situated in the NE of the Flanders region in Belgium, at the Dessel nuclear site and a surrounding safety area on the territory of the Dessel-Geel-Kasterlee communities (Fig. 1).
This field test campaign consisted in seven cored and logged boreholes and of about 200 CPTs (depth up to $35 \mathrm{~m}$ ) in a regular grid of $\sim 1 \mathrm{~km}^{2}$ over an area of $\sim 60 \mathrm{~km}^{2}$ in the Dessel-GeelKasterlee area.

This area is situated in a geological setting where, under a thin (1-4 m) cover of Quaternary sediments, Miocene sandy sediments outcrop (Fig. 1).

In some preliminary minor field campaigns one of the cored boreholes revealed the presence of a $\sim 10 \mathrm{~m}$ thick clayey layer on a stratigraphic level that was supposed to be sandy.

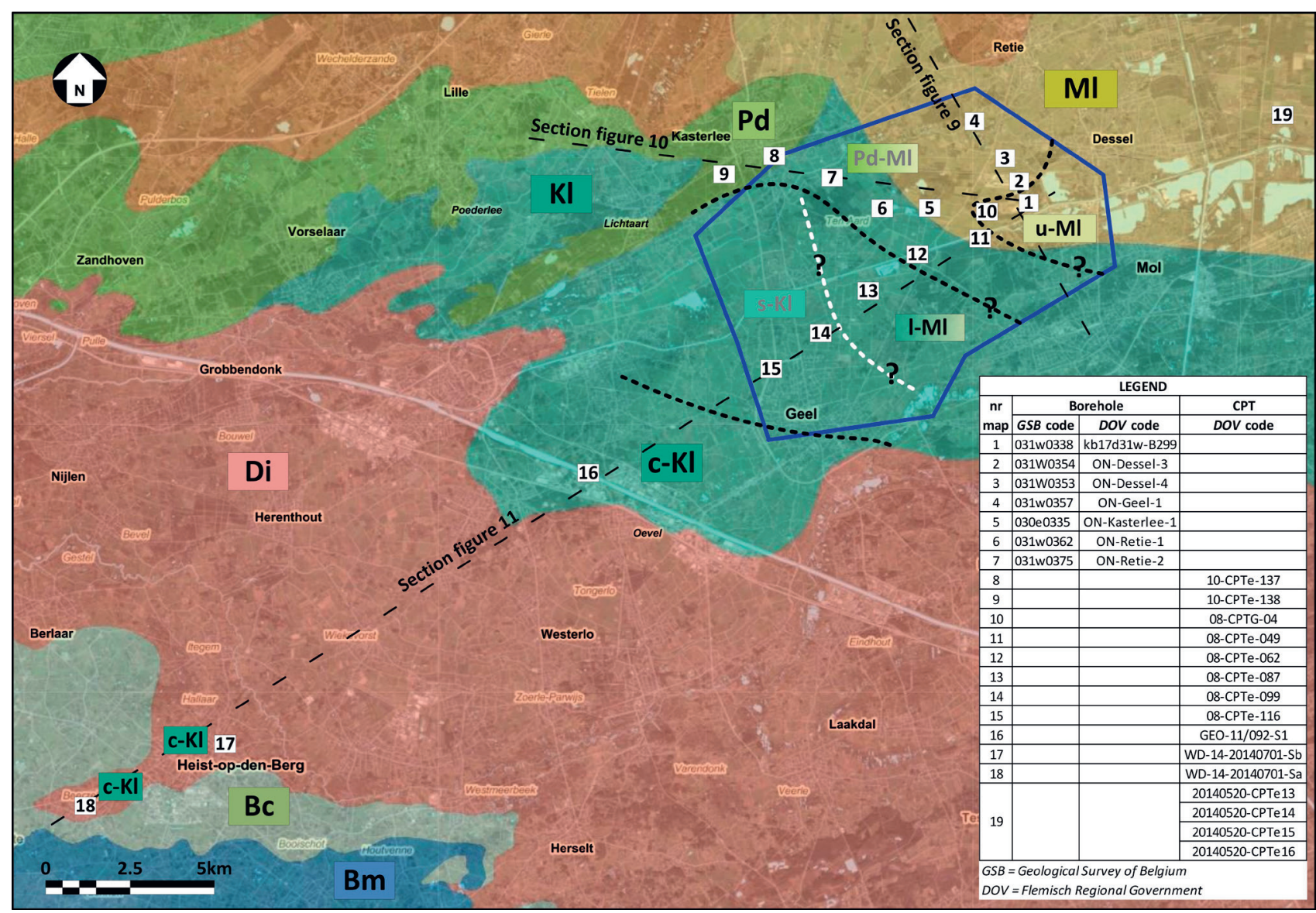

Figure 1. Geologic base map (Schiltz et al., 1993); ONDRAF/NIRAS field test area (blue contour line) with a proposal of approximate boundaries between CPT derived units (dashed lines); $\mathrm{Bm}=$ Boom Formation (clay), $\mathrm{Bc}=$ Berchem Formation (glauconitic sand), Di $=$ Diest Formation (glauconitic sand), $\mathrm{c}-\mathrm{Kl}$ = clayey Kasterlee, s-Kl (L-Ml?) = sandy unit between 1-Ml and c-Kl interpreted as reworked c-K1 at the base of 1-Ml (Vandenberghe et al., 2020, this volume; Adriaens \& Vandenberghe, 2020, this volume), L-Ml = lower Mol sand, U-Ml = upper Mol sand, Pd-Ml = lateral sandy equivalent between Pd and Ml, Pd = Poederlee Formation (sand). 
Obviously the primary objective of the large number of CPTs was determining the presence and extension of this aquitard. It turned out that these data were also valuable in the discussion of the complex detail stratigraphy of the area. Therefore CPT data have been integrated in the unravelling of the local stratigraphy as presented in Vandenberghe et al. (2020, this volume).

More information on the CPTs and boreholes (see also table on Fig. 1) referred to in this paper can be consulted on https://www.dov.vlaanderen.be/data/opdracht/2020-022689.

\section{Method}

\subsection{Presentation of the method}

At the time of the 2008 ONDRAF/NIRAS CPT campaign, mechanical CPTs were still predominantly in use in Belgium. Cone resistance is than the only relevant parameter to interpret lithology and is only appropriate to some extent to distinguish between clay and sand layers. When used, soil interpretation from CPTs with electrical cone was mainly based on a qualitative analysis from cone resistance (qc) and local friction (fs) (NEN $5140,1996)$

As far as known no soil type interpretation methods of more recent date have been used in Belgium until 2008. Nevertheless a lot of research has been done since the eighties of the last century. Results and experience are made available through a large number of publications.

Because of lacking experience with soil type interpretation methods, it took some trial and error period with some methods (Searle, 1979; Douglas \& Olsen, 1981) in a preliminary stage of the CPT interpretations. From the amount of available literature it was decided to continue with the soil type behavior (SBT) charts from Robertson (1990) and Robertson et al. (1986). They are easy to apply (raw qc and Rf measurements are used), have a robust scientific foundation, and are commonly and worldwide in use.

For the CPTs from the 2008 ONDRAF/NIRAS campaign the application of the original SBT chart (Robertson et al., 1986) was focused on the aquitard that proved to be present throughout the whole study area. They were used in an attempt to characterize a semi quantitative "clayeyness" of the observed aquitard (Schiltz, 2008).

Improvements in the lithostratigraphic interpretation of other geological units in the area remained modest (Schiltz, 2008; Rogiers et al., 2010) although some soil behavior type features were observed that seemed to be promising for further analysis of some, difficult to identify, units (Mol and Poederlee Formations).

The 2010 field test campaign coincided with the publication of an update of CPT based soil type interpretation and equation for calculating soil type behavior index I (Robertson, 2010a) and of estimating hydraulic conductivity $\mathrm{k}_{\mathrm{SBTn}}$ (Robertson, 2010b).

The application of the latter for new CPTs in the vicinity of logged and cored borehole locations of the 2008 campaign revealed the observation of close analogy between CPT derived $\mathrm{k}_{\mathrm{SBTn}}$ (and I) - -log with borehole gamma ray log.

CPTs from the 2008 field campaign throughout the study area were reprocessed for a number of sections and the correlation of the CPT derived $\mathrm{k}_{\mathrm{SBTn}} \log$ proved to be a big improvement for the stratigraphic interpretation and understanding of the stratigraphy in the area (Wouters \& Schiltz, 2013).

The ONDRAF/NIRAS CPT campaigns consisted merely of classic electric cone penetration tests (CPTE). A minor number electric CPTs with pore pressure measurement (CPTU), conductivity (CPTR) and natural gamma (CPTG) were executed. Theoretically, pore pressure measurement provides an improvement for soil profiling. As no significant difference was observed between results from CPTE and CPTU for the interpretations discussed in this paper, and because of the large number of CPTE compared to the other CPTs, all CPTs were treated in the same way for consistency of the interpretations.

In the following section the CPT technique, the difference with Gamma ray logging and the principle of CPT derived I and $\mathrm{k}_{\mathrm{SBTn}}$ is briefly discussed. It is followed by a section which showcases some results of the CPT-GR analogy and its consistent results for stratigraphic interpretation in the ONDRAF/
NIRAS study area. Some other cases are briefly discussed to demonstrate how the $\mathrm{I}_{\mathrm{c}}\left(\right.$ and/or $\left.\mathrm{k}_{\mathrm{SBTn}}\right) \log$ responses have been used successfully in other situations.

\subsection{Cone penetration test vs. gamma ray logging}

Analogy between CPT results and borehole gamma ray (GR) log results is not straightforward because of the intrinsic difference of measured features and measuring techniques.

During cone penetration test, a special instrumented cone (electric or piezometric) is pushed into the soil at a constant speed. The classic measured parameters are the resistance of the cone tip (qc) and the friction along the surface of a sleeve above the cone tip (sleeve friction or local friction $\mathrm{fs}$ ). Both parameters are the result of a mechanical reaction between the conus with sleeve and the soil (Fig. 2A). All other parameters such as $I_{c}$ and $\mathrm{k}_{\mathrm{SBTn}}$ are derived from these two raw measured parameters. Typically CPTs are used for geotechnical issues.

Common borehole gamma logging consists in lowering a tool in a predrilled borehole and recording the natural gamma radiation in the sediments (potassium, thorium and uranium) that are present in organic matter and the lattice of minerals in the sediments. Common minerals in sediments in the ONDRAF/ NIRAS study area that incorporate such radioactive elements are in particular illite in the clay fraction and muscovite, glauconite pellets, K-feldspar in the sand fraction. The resulting log thus represents the variations of a chemical soil feature.

The observed analogy between the gamma-log and $\mathrm{k}_{\mathrm{SBTn}}$ (or $\left.I_{c}\right) \log$ can be explained partly because both parameters reflect a measure of clay content that is influenced by the sand-clay size fraction ratio but also by the glauconite and muscovite content in the sand fraction.

The results of borehole logs are typically used for sequence stratigraphy analysis in oil and gas exploration. GR log shapes (Fig. 3) reflect unconformities, sequence boundaries and sedimentation cycles (Emery \& Myers, 1996; Rider, 1999; Krassay, 1998). A proxy of these parameters is offered by the CPT-derived parameters $\mathrm{k}_{\mathrm{SBTn}}$ (or $\mathrm{I}_{\mathrm{c}}$ ) whose vertical log can be interpreted in an analogous way to the GR signal.

\subsection{Cone Penetration Test interpretation}

A brief discussion about the theoretical base behind the CPTderived parameters $I_{c}$ and $k_{\mathrm{SBTn}}$ is presented below. For more background and detailed information reference is made to the extensive list of excellent publications of the research and experience of Robertson and colleagues (a.o. 1990, 2009, 2010a, 2010b, 2016).

From two raw CPT parameters, cone resistance $\mathrm{q}_{\mathrm{c}}$ and sleeve friction $\mathrm{f}_{\mathrm{s}}$, the friction ratio $\mathrm{R}_{\mathrm{f}}$ is calculated:

$$
\mathrm{R}_{\mathrm{f}}=\mathrm{f}_{\mathrm{s}} / \mathrm{q}_{\mathrm{c}} \times 100 \%
$$

In general, coarse-grained sediments have high $\mathrm{q}_{\mathrm{c}}$ and low $\mathrm{R}_{\mathrm{f}}$ values whereas the opposite is true for fine-grained sediments.

Soil behavior charts like Robertson's (1990, 2010a, 2016) and Robertson et al.'s (1986) basically use $\mathrm{q}_{\mathrm{c}}$ and $\mathrm{R}_{\mathrm{f}}$ to define soil behavior types. These SBTs represent the behavior of the corresponding type of soils and mostly, but not necessary, coincide with their physical characteristics (e.g. granulometry, plasticity) and behavior (e.g. stiffness, compressibility).

Figure 2B illustrates an updated $\mathrm{SBT}_{n}$ chart (Robertson, 2010a) based on normalized equivalents of cone resistance and friction ratio. Using normalized parameters is a better practice in general because both $\mathrm{q}_{\mathrm{c}}$ and $\mathrm{f}_{\mathrm{s}}$ tend to increase with depth due to the increase of overburden stress.

Robertson (2010b) presented a modified equation of SBT index $I_{c}$ that essentially represents the radius of concentric circles that define the boundaries between the different soil types in the $\mathrm{SBT}_{n}$ classification chart of Robertson (1990, 2009): $I_{c}=\left(\left(3.47-\log Q_{t}\right)^{2}+\left(\log F_{r}+1.22\right)^{2}\right)^{0.5}$

where: $Q_{t}=$ the normalized (corrected for overburden stress) cone resistance

$\mathrm{F}_{\mathrm{r}}=$ the normalized friction ratio

The table in Figure 2C (Robertson, 2010a) lists the different soil behavior types $\mathrm{SBT}_{n}$, their corresponding range of $\mathrm{I}_{c}$ values and of $\mathrm{k}_{\mathrm{SBTn}}$ values. 


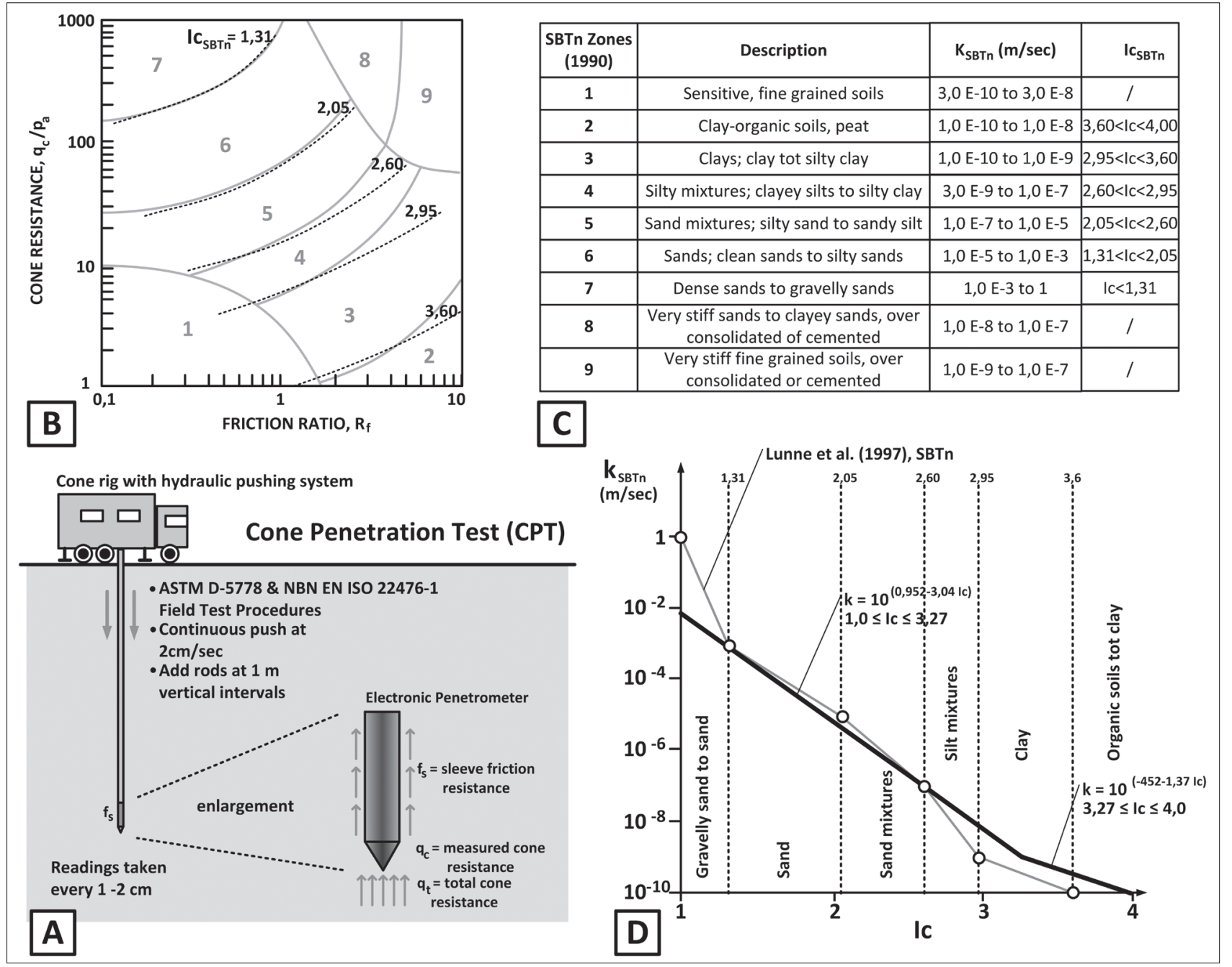

Figure 2. Cone penetration testing (CPT) and interpretation. A: CPT method showing a ballasted rig and an electric piezometric cone and the measured parameters. B: SBT (normalized soil behavior types) chart with normalized cone resistance and friction ratio (Robertson, 2010a) showing the $\mathrm{I}_{\mathrm{c}}$ as concentric circles corresponding with the $\mathrm{SBT}_{\mathrm{n}}$ boundaries (2 to 7). C: table (Robertson, 2010b) with normalized soil behavior types and corresponding I (normalized soil behavior index) and $\mathrm{k}$ intervals (proposed values in Lunne et al., 1997). D: diagram representing suggested variation of $\mathrm{k}$ vs normalized Ic (Robertson, 2010b).

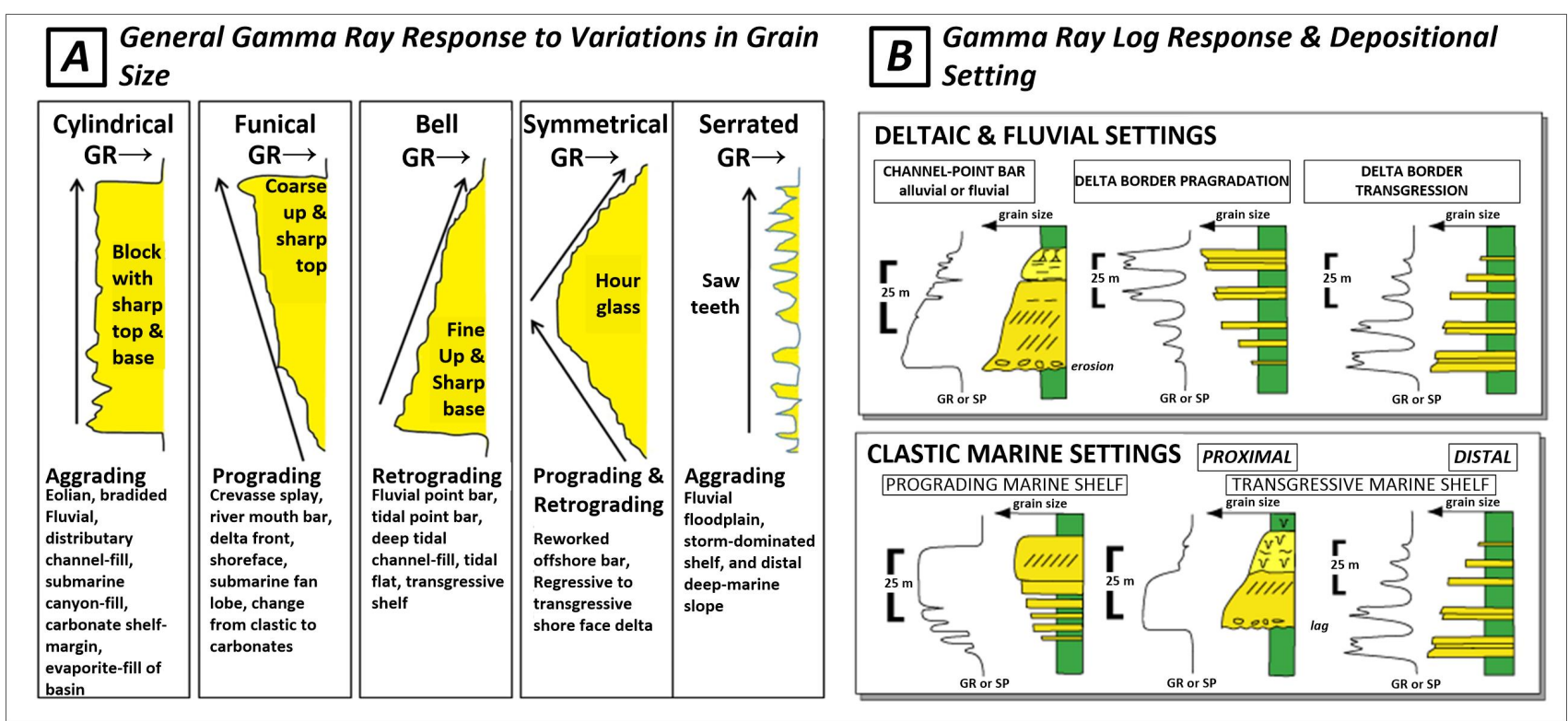

Figure 3. Gamma ray (GR) log response features and shapes for typical sedimentation settings used in a similar way to some extent for correlating units between CPT-derived $\mathrm{k}_{\mathrm{SBTn}}$ (or I $\mathrm{c}_{\mathrm{c}}$ logs. A: Emery \& Meyers (1996) B: Rider (1999), Krassay (1998); in SEPM, 2015. 
Figure 2D shows the graph that illustrates the relationship between $\mathrm{I}_{\mathrm{c}}$ and $\mathrm{k}_{\mathrm{SBTn}}$, from which a value of $\mathrm{k}_{\mathrm{SBTn}}$ can be calculated from each calculated $\mathrm{I}_{\mathrm{c}}$.

Robertson (2010b) presented the following equations that give approximate estimates (!) for soil permeability:

$$
\begin{aligned}
& \mathrm{k}_{\mathrm{SBTn}}=10^{0.952-3.04 \mathrm{Ic}} \quad \text { for } \mathrm{I}_{\mathrm{c}} \leq 3.27 \\
& \mathrm{k}_{\mathrm{SBTn}}=10^{-4.52-1.37 \mathrm{Ic}} \quad \text { otherwise }
\end{aligned}
$$

Sometimes, specific lithology or consolidation characteristics of soils result in underestimated $\mathrm{k}_{\mathrm{SBTn}}$ values. For example in the case of the glauconitic coarse sand of the Diest unit (see section 3.1.3) the high friction ratio gives clayey $\mathrm{SBT}_{n}$, high $\mathrm{I}_{\mathrm{c}}$ and low $\mathrm{k}_{\mathrm{SBTn}}$ values. This effect can be explained from the crushing into clay of the glauconite (clay mineral) particles during penetration of the cone. A similar effect can be observed in overconsolidated sand with high friction ratio values.

\section{Stratigraphic interpretation based on CPTs: some examples}

\subsection{Case of the Neogene in the Kasterlee-Dessel-Geel area in Belgium}

\subsubsection{General outline}

Figure 1 represents the mapped lithostratigraphic units (DOV, 2020) like assumed before the ONDRAF/NIRAS field site campaigns (blue contoured area on Fig. 1). The outcropping sediments are all of Miocene and Pliocene age and consist essentially of sand where the Pliocene sands show little contrast making stratigraphic interpretations of borehole samples difficult and uncertain (Vandenberghe et al., 2020, this volume).

In the study area outlined in Figure 1, an integrated stratigraphic study led to the recognition of six Neogene stratigraphic units, four of which are newly proposed subdivisions that consistently can be correlated in the study area (Vandenberghe et al., 2020, this volume)

Table 1 shows the lithostratigraphic relationship of these mapped units (respectively stating the existing geological interpretation, a recent update and a proposal for the ONDRAF/ NIRAS study area based on the CPT $\operatorname{logs}$ ), while an overlay on the map attempts to display the boundaries between the CPT derived units based on the $\mathrm{I}_{\mathrm{c}}-\mathrm{k}_{\mathrm{SBTn}} \log$ analogy with the GR $\log$.

\subsubsection{Methodology for a CPT interpretation and correlation} approach

The observation of the close relationship of the CPT derived hydraulic conductivity $\left(\mathrm{k}_{\mathrm{SBTn}}\right)$ and the normalised soil behavior type index (I) with the borehole gamma log (GR) and, to a much lesser extent, the electric resistivity log (RES), improved considerably the recognition of the different units in the ONDRAF/NIRAS study area. This was especially true for the Pliocene sandy units that are in this area characterized by a low lithologic contrast.

The CPT-GR correlation is illustrated for three (Figs 4, 5 \& 6 ) of the seven logged and cored boreholes in the research area to show the responses for the different units and their boundaries.

The classical geologist's approach is applied. It consists in a characterisation by using pattern changes and trends in the CPT logs and comparing them with the patterns and trends from the GR logs, the core descriptions and granulometry, determined on samples taken every $2 \mathrm{~m}$.

Relative changes and trends of the different parameters generally are of greater importance than their absolute values.

Trends or changes of the classic parameters $q_{c}, f_{s}$ and $R_{f}$ do in general well for establishing the typical clay and sand alternations in a unit. As most of the sediments concerned are sandy with low lithologic contrast, the consistancy of these parameters is much lower.

Sometimes they confirm the boundaries or the unit interval of the stratigraphic units defined by the $\mathrm{k}_{\mathrm{SBTn}}\left(\mathrm{I}_{\mathrm{c}}\right)$ and gamma log trend analogies, which show on the other hand excellent consistancy.

Objective trend lines, that can be established in standard spread sheet program for these parameters, have been represented on the correlation graphs (see Figs 4, 5 \& 6).

Because of the high similarity of the CPT derived log subdivisions and the GR-RES established stratigraphy, stratigraphic correlations using only CPT logs, can be made in much the same way as geologists correlate classical geophysical borehole logs. Therefore the CPT log data have significantly contributed to establish the reliability and robustness of the integrated stratigraphy in Vandenberghe et al. (2020, this volume). Even in a case where no GR nor Resistivity log are available (ON-Geel-1 borehole) and even without a borehole (Poederlee hill, 10-CPTe-138), CPT data could be used to establish a succession comparable to the established stratigraphic succession in that area (Fig. 7).

Therefore CPT characterisation of the established stratigraphic units can now be added for the ONDRAF/NIRAS research area.

In what follows the description of the CPT characteristics, where needed extended with the description of some crucial other characteristics from borehole logs, granulometry or sample descriptions (Wouters \& Schiltz, 2013; Vandenberghe et al., 2020, this volume) is discussed for each of the identified

\begin{tabular}{|c|c|c|c|c|c|c|c|c|c|}
\hline \multicolumn{8}{|c|}{ LITHOSTRATIGRAPHY } & \multirow{3}{*}{\multicolumn{2}{|c|}{$\begin{array}{c}\text { CHRONO- } \\
\text { STRATIGRAPHY }\end{array}$}} \\
\hline \multirow{2}{*}{\multicolumn{2}{|c|}{$\begin{array}{c}\text { 1993-1995 (1) } \\
\text { FORMATION }\end{array}$}} & \multirow{2}{*}{\multicolumn{2}{|c|}{$\begin{array}{c}2019 \text { (VPO) } \\
\text { FORMATION }\end{array}$}} & \multicolumn{4}{|c|}{2020 (ONDRAF/NIRAS study area) } & & \\
\hline & & & & \multicolumn{4}{|c|}{ FORMATION (*=informal, grey=uncertain) } & & \\
\hline $\mathbf{W}$ & E & $\mathbf{W}$ & $\mathbf{E}$ & $\mathbf{W}$ & \multicolumn{2}{|c|}{ Transition } & $\mathrm{E}$ & & \\
\hline BRASSCHAAT & \multirow{3}{*}{$\begin{array}{l}\mathrm{MOL} \\
\text { (MI) }\end{array}$} & \multicolumn{2}{|c|}{ MERKSPLAS (Me) } & & & & & \multirow{8}{*}{ NEOGENE } & \multirow{3}{*}{ PLIOCENE } \\
\hline & & \multirow{2}{*}{$\begin{array}{l}\text { POEDERLEE } \\
(\mathrm{Pd})\end{array}$} & \multirow{2}{*}{$\begin{array}{l}\mathrm{MOL} \\
\text { (MI) }\end{array}$} & \multirow{2}{*}{$\begin{array}{l}\text { POEDERLEE } \\
(\mathrm{Pd})\end{array}$} & $\begin{array}{l}\mathrm{Pd}-\mathrm{MI}(*) \\
\end{array}$ & $\begin{array}{l}\mathrm{Pd}-\mathrm{Ml}(*) \\
\end{array}$ & & & \\
\hline $\begin{array}{l}\text { POEDERLEE } \\
(\mathrm{Pd})\end{array}$ & & & & & & u-MI $\left({ }^{*}\right)$ & u-MI $(*)$ & & \\
\hline \multirow{3}{*}{\multicolumn{2}{|c|}{$\begin{array}{l}\text { KASTERLEE } \\
\text { (KI) }\end{array}$}} & \multirow{3}{*}{\multicolumn{2}{|c|}{$\begin{array}{l}\text { KASTERLEE } \\
(\mathrm{KI})\end{array}$}} & KASTERLEE & $\mathrm{I}-\mathrm{Ml}(*)$ & $\mathrm{I}-\mathrm{MI}(*)$ & $\mathrm{I}-\mathrm{Ml}(*)$ & & \multirow{5}{*}{ MIOCENE } \\
\hline & & & & $(\mathrm{KI})$ & $s-K I(I-M I ?)$ & s-KI (I-MI?) & S-KI (I-MI?) & & \\
\hline & & & & & & & & & \\
\hline \multicolumn{2}{|c|}{ DIEST (Di) } & \multicolumn{2}{|c|}{ DIEST (Di) } & \multicolumn{4}{|c|}{$\frac{\mathrm{C}-\mathrm{KI}(\mathrm{)})}{\mathrm{DIEST}(\mathrm{Di})}$} & & \\
\hline \multicolumn{2}{|c|}{ BERCHEM (BC) } & \multirow{2}{*}{\multicolumn{2}{|c|}{$\frac{\mathrm{BERCHEM}(\mathrm{BC})}{\mathrm{BOOM}(\mathrm{Bm})}$}} & \multicolumn{4}{|c|}{ BERCHEM (BC) } & & \\
\hline \multicolumn{2}{|c|}{$\mathrm{BOOM}(\mathrm{Bm})$} & & & \multicolumn{4}{|c|}{$\mathrm{BOOM}(\mathrm{Bm})$} & \multicolumn{2}{|c|}{ OLIGOCENE } \\
\hline
\end{tabular}
units following their stratigraphic position.

(1) Schiltz et al. (1993), Gullentops \& Vandenberghe (1995)

Table 1. Lithostratigraphic table; (1) Schiltz et al. (1993); Gullentops \& Vandenberghe (1995); VPO (Vlaams Planbureau voor Omgeving) (2019); Bm $=$ Boom Formation (clay), Bc = Berchem Formation (glauconitic sand), Di = Diest Formation (glauconitic sand), c-Kl= clayey Kasterlee, s-K1 (l-Ml?) $=$ sandy unit between 1-Ml and c-Kl interpreted as reworked c-K1 at the base of 1-Ml (Vandenberghe et al., 2020, this volume; Adriaens \& Vandenberghe, 2020, this volume), $1-\mathrm{Ml}=$ lower Mol sand, u-Ml = upper Mol sand, Pd-Ml = lateral sandy equivalent between Pd and Ml, Pd = Poederlee Formation (sand). 


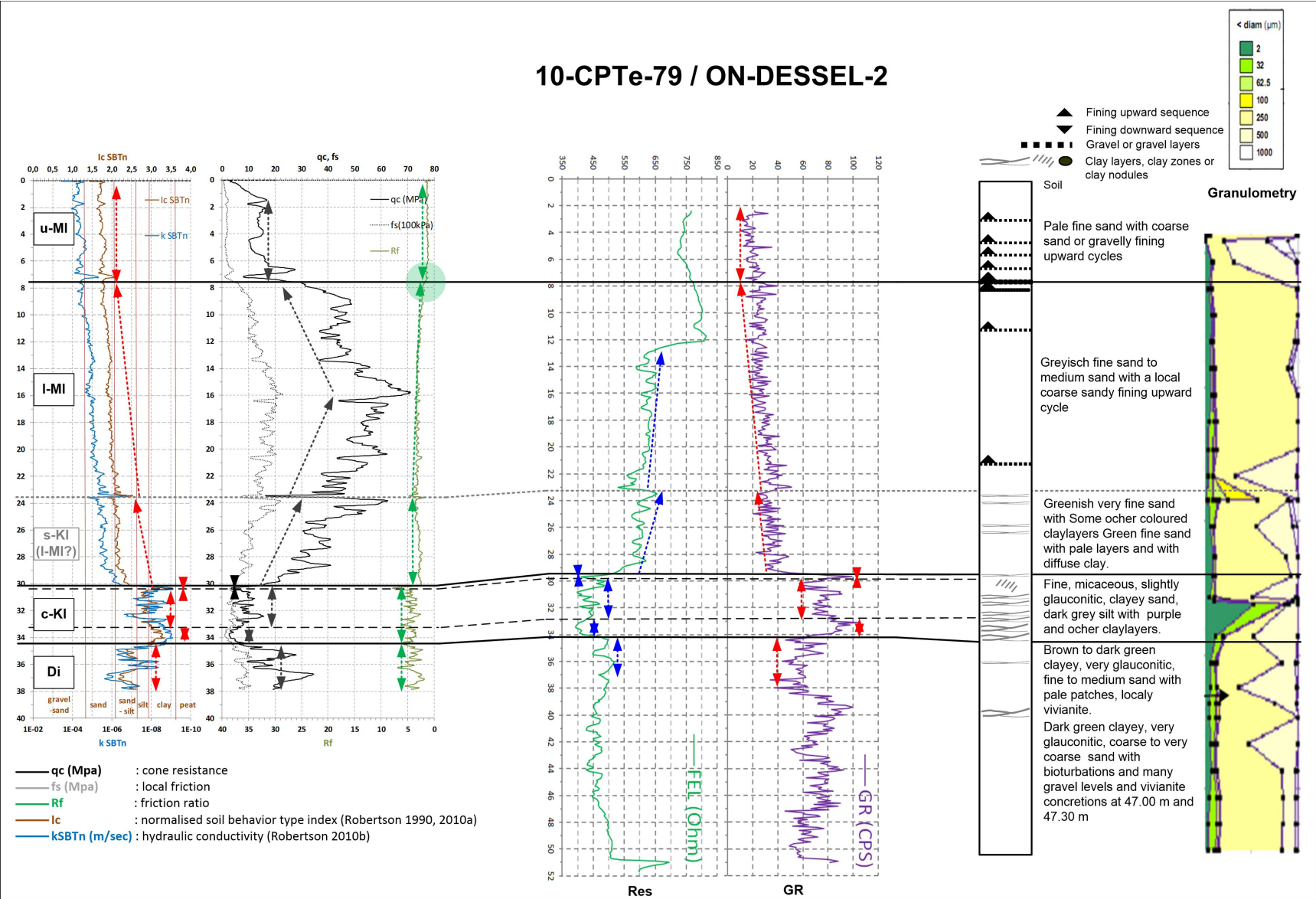

Figure 4. Correlation of CPT logs with cored and logged borehole ON-DESSEL-2 illustrating the consistent CPT-derived $\mathrm{k}_{\mathrm{SBT}}\left(\mathrm{I}_{\mathrm{c}}\right) \log$ response analogy with GR $\log$ response.

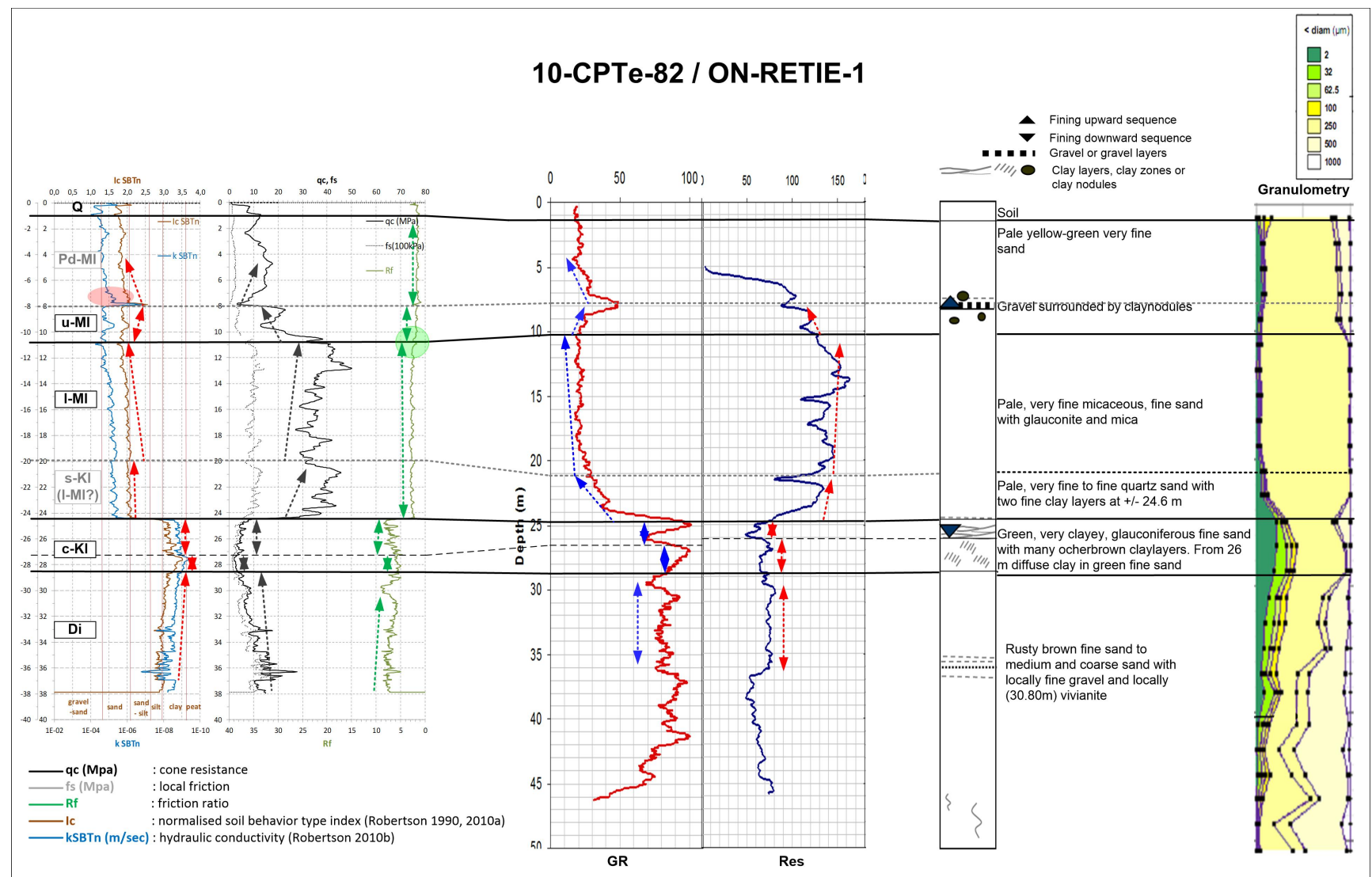

Figure 5. Correlation of CPT logs with cored and logged borehole ON-RETIE-1 illustrating the consistent CPT-derived $\mathrm{k}_{\mathrm{SBTn}}\left(\mathrm{I}_{\mathrm{c}}\right) \log$ response analogy with GR $\log$ response. A Pd-Ml unit is defined above the l-Ml unit, showing a similar response with the Pd unit on the Kl unit in the Kasterlee hill and a different response with the response of the $\mathrm{u}-\mathrm{Ml}$ unit in the other boreholes. 


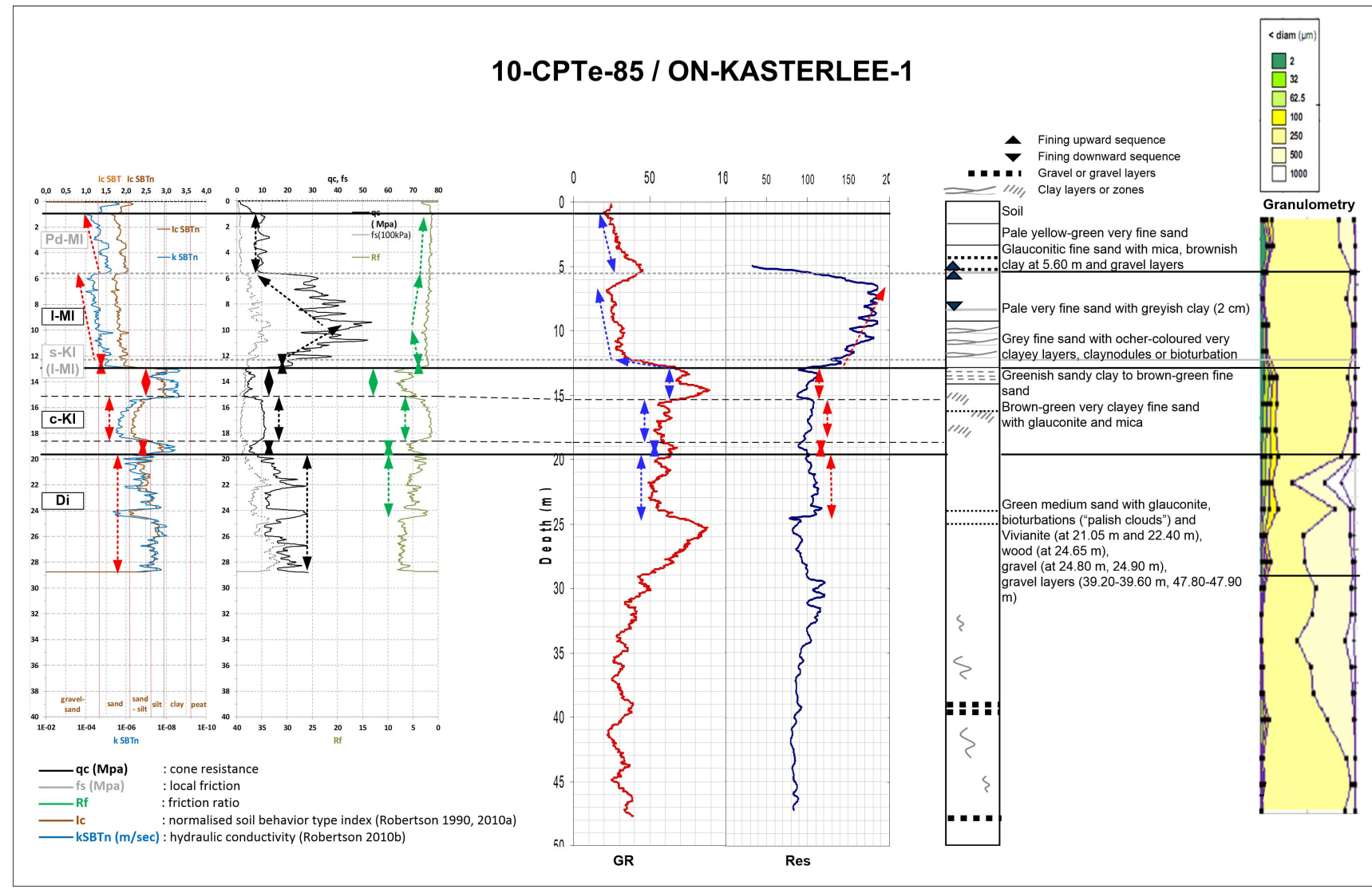

Figure 6. Correlation of CPT logs with cored and logged borehole ON-KASTERLEE-1 illustrating the consistent CPT-derived $\mathrm{k}_{\mathrm{SBT}}\left(\mathrm{I}_{c}\right) \log$ response analogy with GR log response. A Pd-Ml unit is defined above the l-Ml unit, showing a similar response with the Pd unit on the Kl unit in the Kasterlee hill and a different response with the response of the $\mathrm{u}-\mathrm{Ml}$ unit in the other boreholes.

\subsubsection{Formal and informal stratigraphic units based on CPT response}

The different CPT derived units are described from bottom to top and compared to the integrated stratigraphic sequence established by Vandenberghe et al. (2020, this volume). The units are indicated on Figures 4 to 10 and the relation with the integrated stratigraphy is shown in Figures 4, 5 and 6.

\section{$\underline{\text { Di unit }}$}

This unit does not crop out in the ONDRAF/NIRAS study area.

Because of the limited depth (maximal up to $12 \mathrm{~m}$ ) reached by CPTs in this geological formation the characterization is not necessarily representative for this Formation as a whole in the studied area.

This unit is lithologically characterized by medium to coarse glauconitic sands and coincides with the Diest Formation.

The $\mathrm{k}_{\mathrm{SBTn}}(\mathrm{I})$ logs are irregular, with medium to low values, showing an overall trend of upwards decreasing values of $\mathrm{k}_{\mathrm{SBT}}$ (respectively increasing values of $\mathrm{I}$ ) in general. The consistency with GR response is mostly clear for each of the borehole locations, but in between the boreholes, the responses can differ and sometimes even show opposing trends. In this sedimentary facies studied short and thin clay lenses and clay rip-up clasts can locally occur and influence the reading of GR and CPT logs.

The boundary between this unit and the c-Kl unit above is well defined by lithological, granulometrical and mineralogical characteristics (Beerten et al, 2010; Adriaens, 2015; Vandenberghe et al., 2020, this volume) and the top of the CPT Di-unit coincides with the top of the Diest Formation.

The top of the Di-unit is mostly characterized by a more or less marked drop or increase of the $\mathrm{k}_{\mathrm{SBTn}}$ value, corresponding with a generally well-marked increase or decrease of the GR log.

However it should also be noted that although the contrast between the Di-unit and the overlying c-K1 unit is commonly well expressed, it may not always be so obvious.
The most probable reason is the high glauconitic content of the Di-unit, causing high friction when being crushing to clay during penetration of the cone. This results in high $\mathrm{Rf}$ values with no or only poor contrast at the boundary between the Di and $\mathrm{c}-\mathrm{K} 1$ units, the latter being typically clayey. This also explains the typical clayey and silty clay SBT returns for the processed $\mathrm{CPTs}$ according to the scheme outlined in Fig. 2B.

\section{c-Kl unit}

This unit is characterized by an irregular $\mathrm{k}_{\mathrm{SBTn}} \log$ with an overall decreasing trend and with low to very low $\mathrm{k}_{\mathrm{SBTn}}$ (high $\mathrm{I}_{\mathrm{c}}$ ) values, expressing the very clayey content of this unit.

In general this unit is characterized by 2 to 3 sublayers (clay/ sand) that are mostly clearly individualized. The correspondence with GR-log is clear and consistent for every location and for the unit as a whole in the studied area.

The consistency is also very clear for the top of this unit where it is characterized by a sharp increase of $\mathrm{k}_{\mathrm{SBTn}_{\mathrm{n}}}$ ( $\mathrm{I}_{\mathrm{c}}$ decrease) and a sharp drop of the GR-log. This boundary is well represented by a response change for all of the $\mathrm{CPT}$ and borehole parameters.

This CPT c-Kl unit is corresponding to the 'clayey Kasterlee' unit described in the integrated stratigraphy of the area by Vandenberghe et al. (2020, this volume).

Importantly under the Lichtaart-Kasterlee hill ridge where control boreholes are lacking, the presence of the c-Kl unit still can be recognized beyond doubt below what is the stratotype Kasterlee Sand unit (see 10 CPTe-138 in Fig. 7).

\section{$\underline{\mathrm{s}-\mathrm{K} 1 \mathrm{unit}}$}

In the CPT logs nearby the control ON-boreholes a few meters at maximum can be individualized as the s-K1 unit just above the c-Kl-unit, equivalent to the 'clayey Kasterlee' unit. This thin s-Kl unit occurs below a thicker and regularly trending l-Ml unit (Figs. 4-10).

In the CPTs this s-K1 unit shows a somewhat irregular $\mathrm{k}_{\mathrm{SBTn}}$ and GR trend, with approximatively constant or slightly increasing $\mathrm{k}_{\mathrm{SBTn}}$ with low to medium values. The top of this 


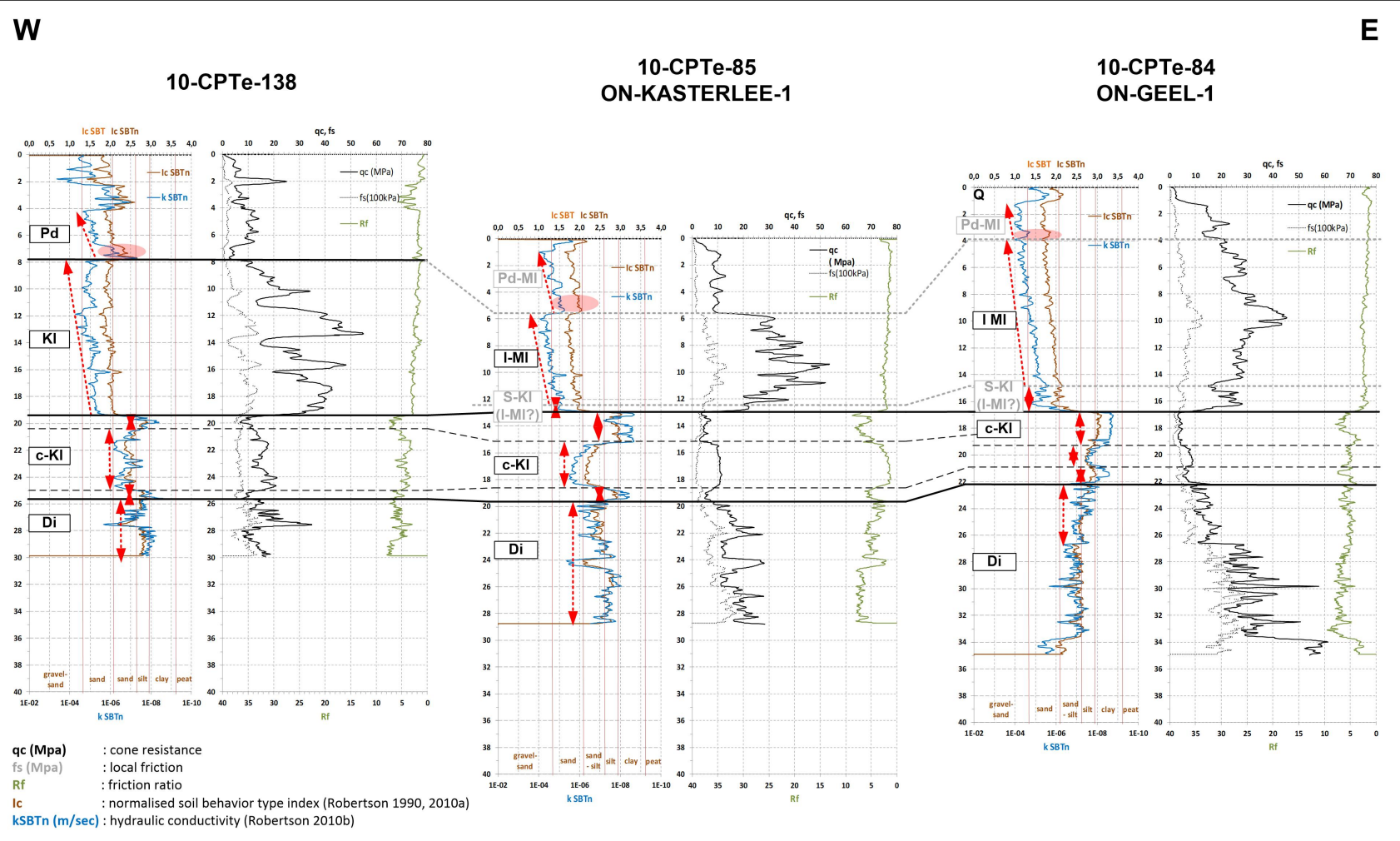

Figure 7. Correlation of CPT logs at cored and logged reference boreholes ON-GEEL-1 and ON-KASTERLEE-1 with the Kasterlee hill reference CPT (10-CPTE-138) illustrating the consistent CPT-derived $\mathrm{k}_{\mathrm{SBTn}}\left(\mathrm{I}_{\mathrm{c}}\right) \log$ response (similar to GR log response) of the different defined units between the CPTs in general and especially the analogy of the CPT log response between Pd and Pd-Ml unit above Kl and l-Ml units.

unit is characterized by a kink of the $\mathrm{k}_{\mathrm{SBTn}}(\mathrm{I}), \mathrm{R}_{\mathrm{f}}$ and GR logs, sometimes combined with a sharp increase or drop.

This unit corresponds to large extent in the CPT close to borehole ON-Dessel-2 where based microfossils Kasterlee Formation was interpreted (Louwye et al, 2007), but the parameter responses in the CPT logs are in general less obvious.

This s-Kl unit has been closely compared to the integrated stratigraphy in many ON-boreholes and the correspondence with the position and thickness of a reworked unit at the base of the 'lower Mol' or 'Kasterlee sensu Gulinck' unit as described in Vandenberghe et al. (2020, this volume) is excellent. It consists of slightly glauconitic and greenish colored sand also influencing the GR and RES logs at the base of the overlying paler grey sand as shown in Figures 5 and 6. This interval was micropaleontologically characterized by Louwye et al. (2007).

\section{1-Ml and K1 units}

This CPT 1-Ml unit occurs in all CPT logs and is several meters thick. It is typically characterized by a gentle increase of $\mathrm{k}_{\mathrm{SBT}}$ (decrease of $I_{c}$ ), generally coinciding with a gentle decrease of GR $\log$.

The top is in general characterized by a maximum of this increasing trend, followed by a pronounced drop in $\mathrm{k}_{\mathrm{SBTn}}$.

Also $\mathrm{R}_{\mathrm{f}}$ shows a consistent kink, mostly with a small drop in value, in its log trend at the boundary between the l-Ml and u-Ml units. This kink coincides with the change between the finer granulometry of 1-Ml and the coarser $\mathrm{u}-\mathrm{Ml}$ as is known from ON-borehole core analyses (Schiltz, 2008; Beerten et al., 2010).

A comparison with the units established in the integrated stratigraphy of the area (Vandenberghe et al., 2020, this volume) and the corresponding GR and RES subdivisions as shown e.g. in Figures 4, 5 and 6, shows an excellent correspondence with the 'lower Mol' or 'Kasterlee sensu Gulinck' unit.

This pale quartz sand unit could geometrically be considered the eastward continuation of the type Kasterlee Sand as is done by Gulinck and coworkers at the Geological Survey of Belgium although lithologically it resembles more the overlying quartz sand of the Mol Formation.

Also it is not clear whether this 'lower Mol' or 'Kasterlee sensu Gulinck' unit is a direct geometrically continuation of the type Kasterlee Sand or if it erodes it. This issue is discussed in
Vandenberghe et al. (2020, this volume) but remains unsolved also because a cored reference borehole in the Kasterlee Sand type area just west of the ON-borehole area is lacking.

The 10-CPTe-138 log is the best information available from that area (Fig.7) and it can be seen that the CPT response of the l-Ml unit very strongly resembles the CPT signature of the Kasterlee Sand in the type area. Both units show a constant trend or a generally gentle increase of $\mathrm{k}_{\mathrm{SBTn}}$ ( $\mathrm{I}_{\mathrm{c}}$ decrease) marked with a sharp drop or kink in the trend of $\mathrm{k}_{\mathrm{SBTn}}\left(\mathrm{I}_{c}\right)$ at the top.

\section{u-Ml units}

This unit is typically represented by medium to coarse white or pale sand, sometimes with several thin fine gravel beds. It occurs in the eastern part of the research area above the l-Ml unit.

The section in the CPT $\mathrm{k}_{\mathrm{SBTn}}$ (I) logs that corresponds with this unit has maximal $\mathrm{k}_{\mathrm{SBTn}}$ values. The high values make up an approximatively constant or slightly increasing trend after a kink at the base. This signature is more or less mirrored by the GR logs. Typically for many of the CPTs the base of this unit is characterized by a kink associated with a small drop in $\mathrm{R}_{\mathrm{f}}$.

Examples of this succession 1-Ml and u-Ml are nearby the boreholes ON-Retie-1, ON-Dessel-3, ON-Dessel-4 and ONDessel-2 (Figs 4, 5 \& 8).

\section{Pd and Pd-Ml units}

To the west, a unit Pd-Ml occurs on top of the u-Ml unit as shown in the CPTs near boreholes ON-Geel-1 and ON-Kasterlee-1 (Figs $6 \& 7$ ). This unit is generally characterized by a sharp drop and lower $\mathrm{k}_{\mathrm{SBTn}}$ (high $\mathrm{I}_{\mathrm{c}}$ ) values at the base followed by an increasing trend of the $\mathrm{k}_{\mathrm{SBTn}} \log$ (decreasing $\mathrm{I}_{\mathrm{c}}$ ).

In some cases the Pd-Ml unit is found above the u-Ml unit as is the case in the CPT log near ON-Retie-1 (Fig. 5) and ONDessel 3 and 4 (Fig. 8). The $\mathrm{k}_{\mathrm{SBTn}}\left(\mathrm{I}_{\mathrm{c}}\right) \log$ response of this unit is clearly different from the one of the u-Ml unit.

The $\mathrm{k}_{\mathrm{SBTn}}\left(\mathrm{I}_{\mathrm{c}}\right) \log$ response of the Pd-Ml unit resembles very well, in particular in the lower part the signal from a CPT across the nearby (just NW of the ONDRAF/NIRAS research area) stratotype Poederlee Formation (10-CPTe-138 in Fig. 7), the CPT Pd-unit. The base of the Poederlee Formation in the CPT is localized based on a nearby incised road where it is characterized by a clayey base with fine gravel (Hukkelberg 


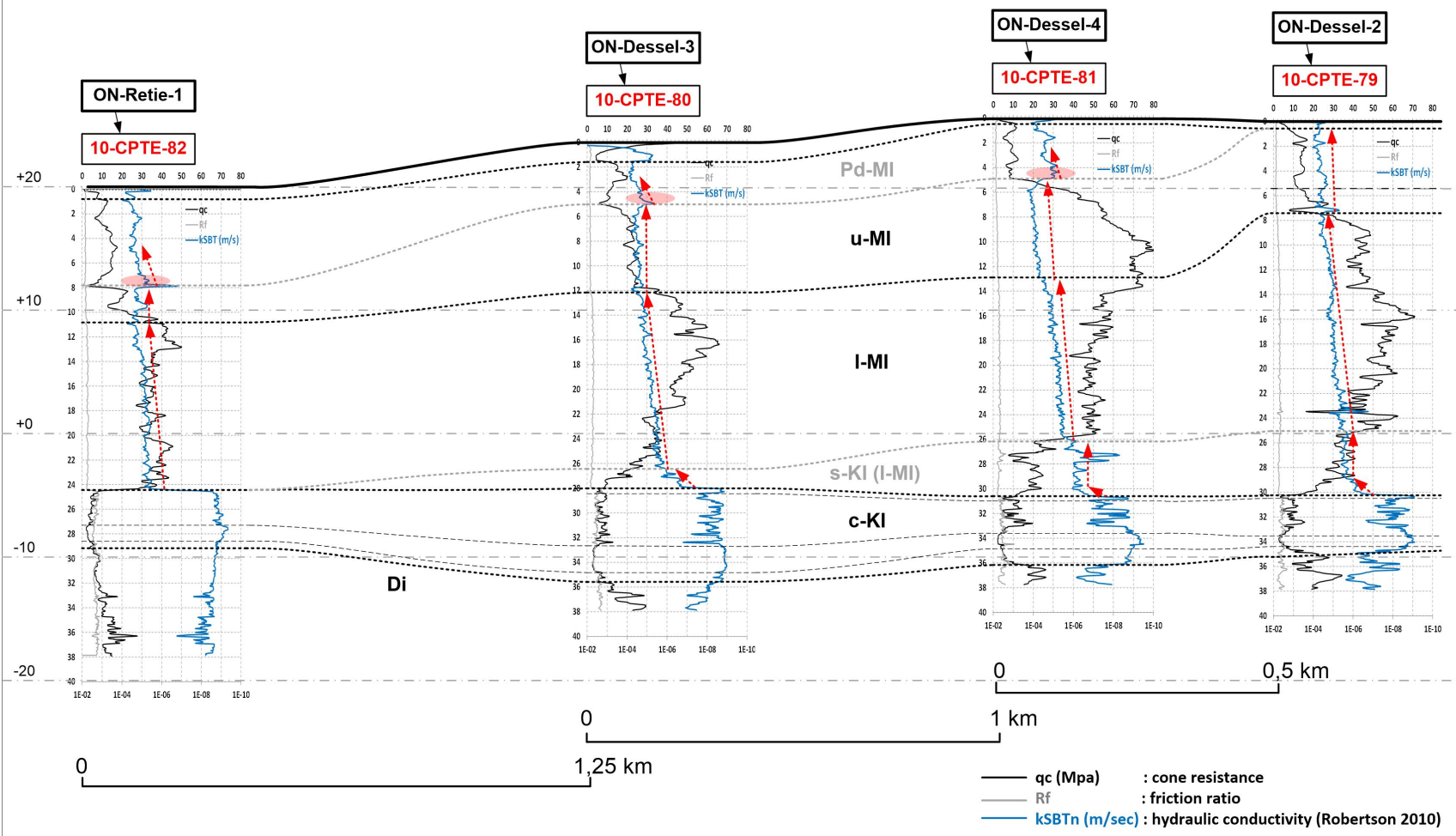

Figure 8. Section of CPTs from the ON-Dessel-2 cored and logged reference borehole to the N over the cored and logged reference boreholes ONDessel-4, ON-Dessel-3 to ON-Retie-1 the ONDRAF/NIRAS study area. Correlations based on CPT derived $\mathrm{k}_{\mathrm{SBTn}}$ log response after calibration with the boreholes. Unit codes see text and Figure 1.

gravel) followed by pale fine sand that is often locally cemented into limonite concretions (DOV TO-20120101 in Vandenberghe et al., 2020, this volume).

The core descriptions (Wouters \& Schiltz, 2013) of some of the boreholes (ON-Retie-1, ON-Kasterlee-1) mention the presence of clay and gravel at or near the lower boundary that is represented by the lower boundary defined by the $\mathrm{k}_{\mathrm{SBTn}}$ trend of the Pd-Ml unit, analogous features that can be observed for the Pd-unit in the Kasterlee hill.

Although the CPT signals suggest the presence of two different lithological units, u-Ml and Pd-Ml, occurring above the 1-Ml unit, the established integrated stratigraphy (Vandenberghe et al., 2020, this volume) only recognizes one single lithostratigraphic unit, namely the Mol Formation corresponding to the $\mathrm{u}-\mathrm{Ml}$ unit.

3.1.4. Stratigraphic correlation profiles in the Kasterlee-DesselGeel area based on the CPT derived units

As the CPT units derived in individual boreholes are consistently recognized in the study area, correlation profiles were constructed to illustrate their potential in describing the geometrical build-up of the area (Figs $8,9 \& 10$ ). The CPT nearby borehole ON-Dessel-2 is present in the three profiles.

As the trends described in the previous section proved to be consistent and matched borehole trends, they were used to correlate these and additional CPTs to create different profiles (Figs $8,9 \& 10$ ). The trends of the different parameters are indicated with arrows in these figures.

The correlations in these sections are straightforward. Some specific observations are discussed below.

In the NS section across the ONDRAF/NIRAS site some detailed vertical variations within the c-Kl or 'clayey Kasterlee' unit appear to occur consistently in the area. The northward thinning of the s-K1 unit, representing sediment at the base of the l-Ml unit reworked from the underlying unit, could point to more intense erosion of $1-\mathrm{Ml}$ into $\mathrm{c}-\mathrm{Kl}$ in the south.

The NS section (Fig. 8) is also added to show the consistency of the $\mathrm{k}_{\mathrm{SBTn}} \log$ between the u-Ml unit and Pd-Ml unit above, characterized by an abrupt but small drop and by a lower-value basal part (indicated by a reddish spot) followed by an increasing trendline of $\mathrm{k}_{\mathrm{SBTn}}$. Such a trend is not observed in the CPT at borehole ON-Dessel-2, where $\mathrm{k}_{\mathrm{SBTn}}$ trend remains at a constant high level after a maximum reached at the boundary with the 1-Ml unit. This section can be interpreted as showing an incision of the Pd-Ml unit, becoming thicker towards the north, into the $\mathrm{u}-\mathrm{Ml}$ unit and thus its younger stratigraphic position.

The WE section (Fig. 9) is compatible with the incision hypothesis. From W to E the Poederlee Formation or Pd-unit extents eastward into the Pd-Ml unit. Both have a similar consistent $\mathrm{k}_{\mathrm{SBTn}}$ signature at their boundary (red spot in Fig.9) that differs from the Mol Formation or u-Ml unit more to the east. This lateral change from Pd-Ml over a short distance east of the ON-Retie-2 borehole location into the u-Ml unit could be erosive but also be just a lateral transition (see also discussion in Vandenberghe et al., 2020, this volume).

In the WE section subdivisions in the c-Kl unit can be followed as is the case in the NS profile. The CPT signal of the $\mathrm{c}-\mathrm{Kl}$ is beyond doubt present under the type Kasterlee Sand, the CPT Kl unit in the hill. The similarity in CPT response between the 1-Ml unit together with its reworked base, the s-Kl unit, and the laterally occurring type Kasterlee Sand or Kl-unit under the hill seems to support a stratigraphic equivalence; the reworked sand unit s-K1 is absent at the base of the Kasterlee Sand in the hill.

The SW-NE section between Heist-op-den-Berg and the ON-Dessel-2 (Fig.10) shows generally two to three subdivisions in the c-Kl that are supported by outcrops on the Heist-opden-Berg hill (see Verhaegen et al., 2020, this volume). The subdivisions in $\mathrm{c}-\mathrm{Kl}$ can be correlated in the CPT log near the Oevel site where a gravel occurs between the Diest and Kasterlee Formations (Verhaegen et al., 2014). Similarly as in the WE section (Fig. 9) but less outspoken, 1-Ml with its basal unit s-Kl seems to grade laterally into unit $\mathrm{Kl}$ resembling type Kasterlee Sand and the Pd-Ml unit laterally (erosive?) into the u-Ml or Mol Formation.

Based on the observed $\mathrm{k}_{\mathrm{SBTn}} \log$ responses in the different sections a stratigraphic relationship is proposed between the seven units above the Miocene Diest Formation (see Figs $1 \& 4$ ).

Different stratigraphic correlation hypotheses between the units defined in the ONDRAF/NIRAS study area and the Kasterlee hill were already presented earlier (Schiltz, 2011). The Kasterlee hill is also the reference location for the younger $\mathrm{Pd}$ 


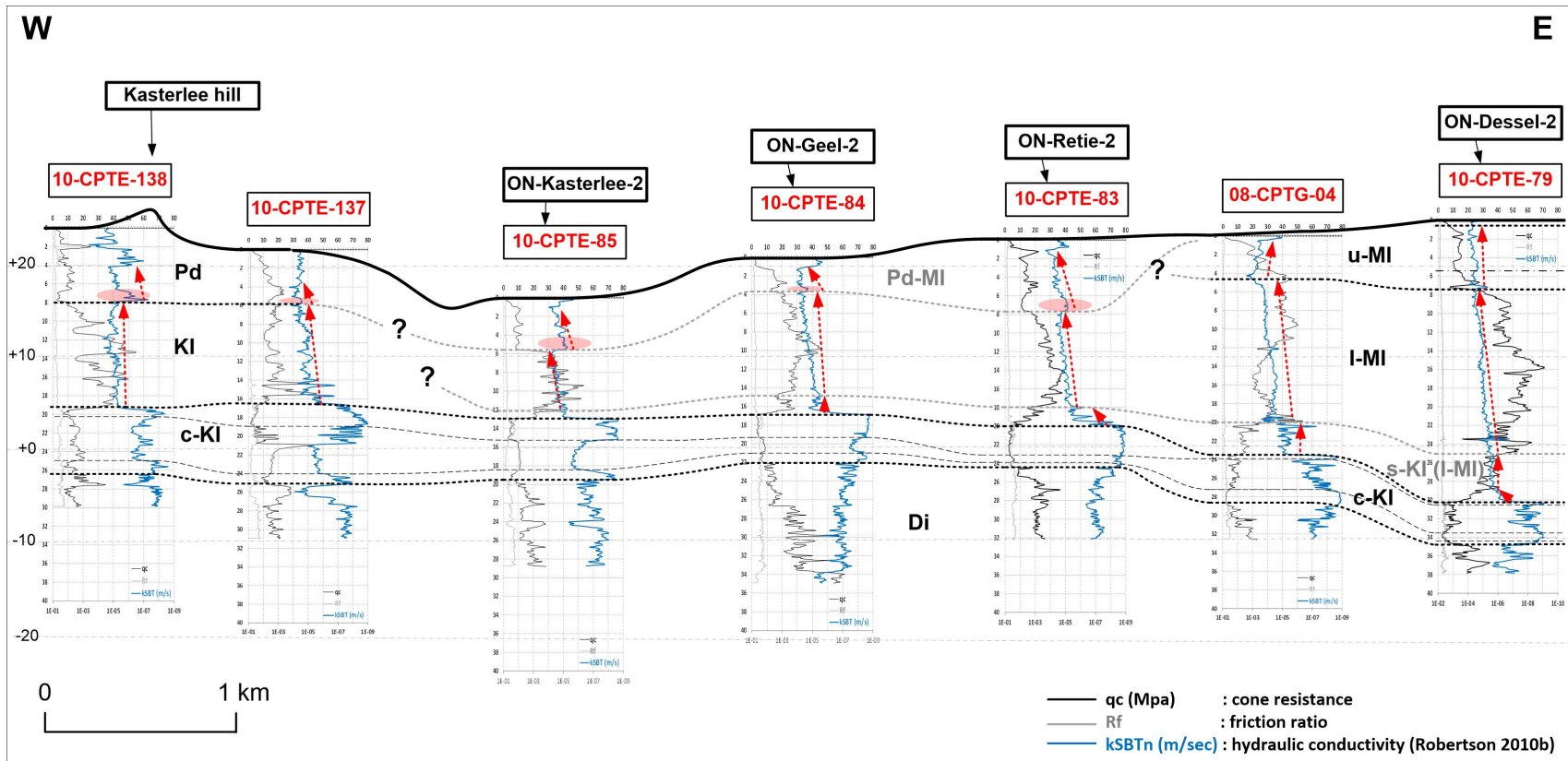

Figure 9. Section of CPTs from the Kasterlee hill over the cored and logged reference boreholes through the ONDRAF/NIRAS study area until the cored and logged reference borehole ON-Dessel-2. Correlations based on CPT derived $\mathrm{k}_{\mathrm{SBT}} \log$ response after calibration with the boreholes. Unit codes see text and Figure 1.

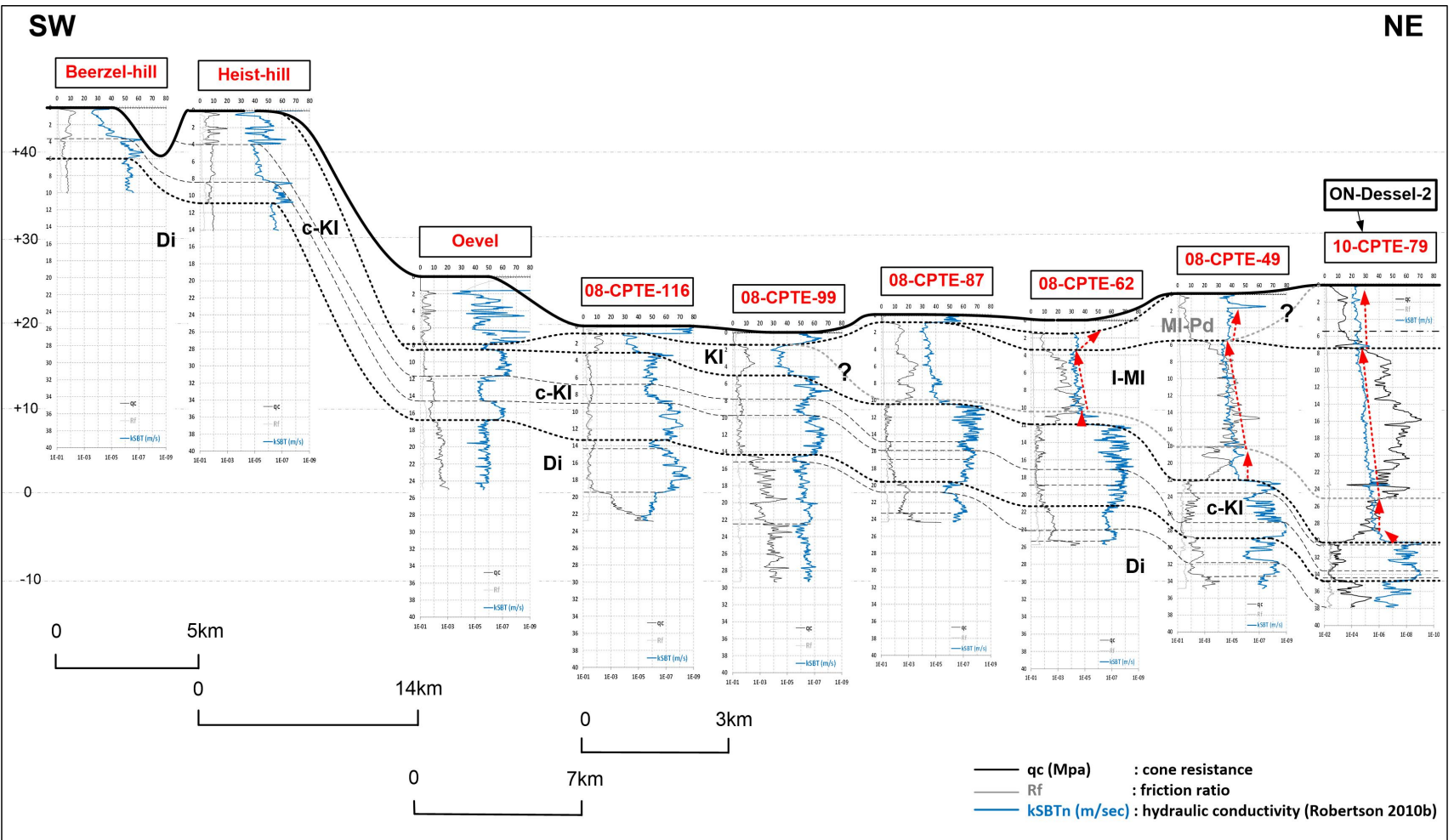

Figure 10. Section of CPTs from the Heist-Op-den-Berg hill over the Oevel outcrop location and through the ONDRAF/NIRAS study area until the cored and logged reference borehole ON-Dessel-2. Correlations based on CPT derived $\mathrm{k}_{\mathrm{SBTn}} \log$ response after calibration with the reference boreholes. Unit codes see text and Figure 1.

unit (i.e. the Pliocene Poederlee Formation) on the Kasterlee Formation. The Pd unit is commonly considered older or possibly equivalent to the Mol Formation or u-Ml unit in the east.

However, in the clayey base with fine gravel of the Pd unit, $\mathrm{cm}$ - to $\mathrm{dm}$-scale concretions of white medium to coarse sand surrounded with a crust of limonite have been observed. They have been mentioned by Gulinck (1960) and Gullentops (1963) and were recently re-examined by Houthuys \& Matthijs (pers. comm., 2019), who interpreted them as lumps of slightly cemented sand that were transported over a short distance during the incision associated with the base of the Poederlee Formation. This sand shows all characteristics of the sand of the $\mathrm{u}-\mathrm{Ml}$ unit.
A routine mineralogical and granulometric analysis of samples taken in the white sand lumps (Verhaeghe \& Vos, Sibelco nv, pers. comm., 2017) confirm the correspondence with u-Ml sand.

This suggests that the sedimentary cycle of the Pd unit cuts into the u-Ml unit and thus confirms the younger stratigraphic position of the $\mathrm{Pd}(\mathrm{Pd}-\mathrm{Ml})$ unit supporting the correlations in the discussion of the sections above.

From Kasterlee to the east, the Pd (or Pd-Ml) unit cuts in the $\mathrm{K} 1 \mathrm{unit}$ at the Kasterlee hill, then into the 1-Ml unit and further to the east in the $\mathrm{u}-\mathrm{Ml}$ unit.

From the south to the north the Pd (or Pd-Ml) unit cuts into the $\mathrm{u}-\mathrm{Ml}$ unit with an increasing thickness to the north and with 
a possible equivalence between the formal Pd-unit and the PdMl unit based on $\mathrm{k}_{\mathrm{SBTn}} \log$ response.

\subsection{Some other illustrative cases of the use of CPT derived parameters $\boldsymbol{k S B T n}$ and $I c$}

3.2.1. Looking for faults in sediments with low lithological contrast

Figure 11 shows part of a profile of closely spaced CPTs executed to find the exact location of a normal fault (Rauw Fault) at a little distance east of the ONDRAF/NIRAS study area (Fig. 1), discussed in the previous section (Verbeeck et al., 2017).The outcropping and deeper sediments are all sandy showing little internal differentiation as they all belong to the Pliocene upper part of the Mol Formation. A profile (EW) of 34 CPTs with 10 $\mathrm{m}$ between each CPT was obtained perpendicular to the fault direction.

A similar approach as discussed in the previous section was used for the informal stratigraphic interpretation of the CPTs.

Figure 11 shows both (A) classic diagrams and (B) CPTderived $\mathrm{k}_{\mathrm{SBTn}}$ (I) logs to illustrate their differing expression of informal units for which a correlation has to be established.
The $\mathrm{k}_{\mathrm{SBTn}}$ (and $\mathrm{I}_{\mathrm{c}}$ ) logs show a much more detailed and consistent log responses that allows to establish a framework of identifiable layers between the CPTs. This revealed a vertical offset of layers between the rightmost two CPTs in the profile, representing the location of the fault.

The $\mathrm{k}_{\mathrm{SBTn}}$ (and $\mathrm{I}_{c}$ ) logs showing a larger consistency of analogous $\log$ responses and trends to establish a succession of layers in each CPT that can easily be recognized in each CPT $\log$, showing their vertical displacement between the last two CPT's in this section, representing the location of the fault.

Using the same method, a correlation of the l-Ml and u-Ml units could be extended CPTs at the west side of the fault to the CPTs near the ON-Dessel-2 borehole. The boundary between the two determined units was recognized at a depth between 38 and $39 \mathrm{~m}$.

Another fault where this method has successfully been used is the Grote Brogel fault (Deckers et al., 2018).

3.2.2. Visualizing Quaternary sediments with high lithological contrast in a river valley

The use of CPT-derived $\mathrm{k}_{\mathrm{SBTn}}$ and $\mathrm{I}_{\mathrm{c}}$ parameters is not limited to lithological interpretations for stratigraphy or sedimentology.

\section{W}

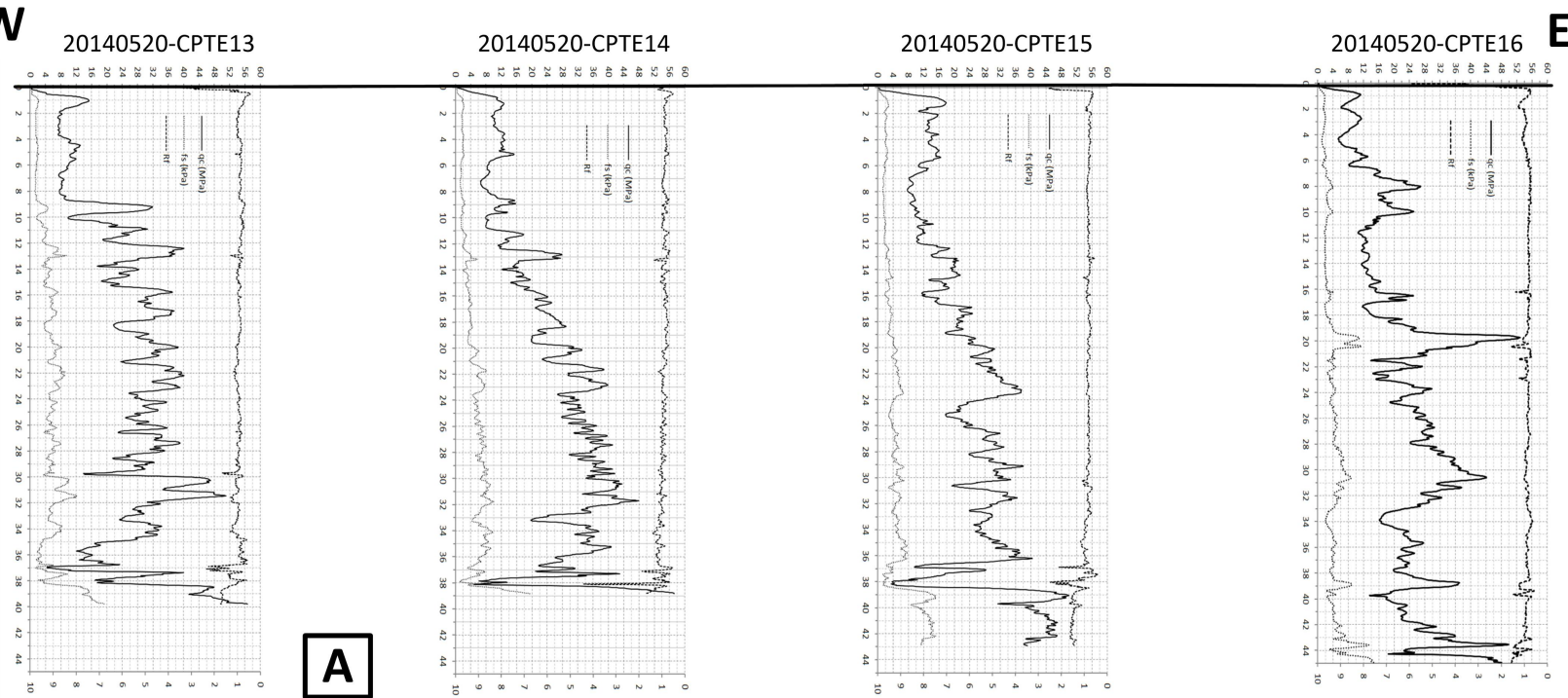

qc (Mpa) : cone resistance

fs : : Local friction

20140520-СРTE13

20140520-CPTE14
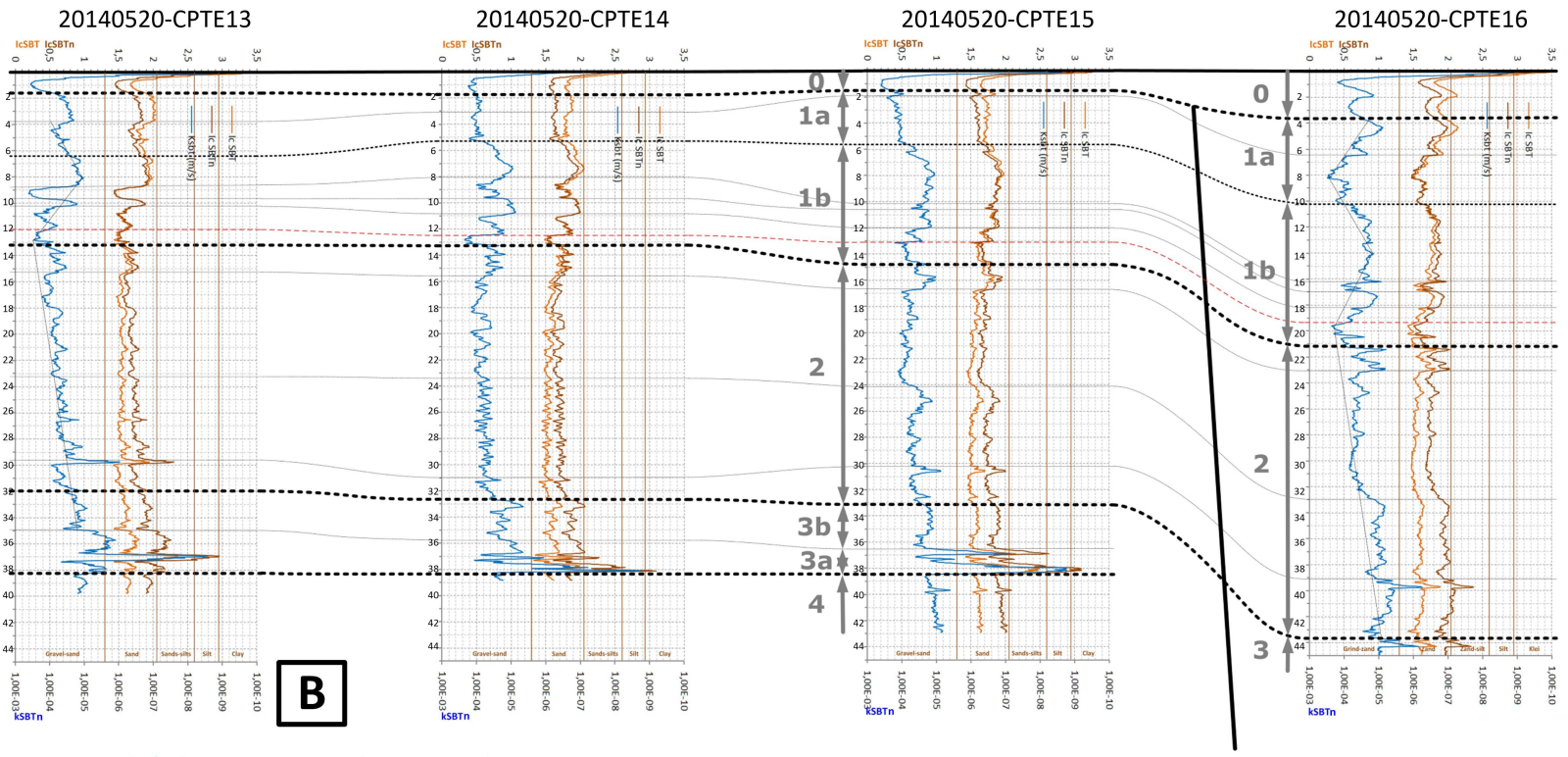

KSBTn (m/sec) : hydraulic conductivity (Robertson 2010b)

- Ic : normalized Soil Behavior Index (Robertson 2010a)

Distance between each CPT is $10 \mathrm{~m}$

Figure 11. Part of the correlation of 40 CPT's in a $10 \mathrm{~m}$ interval for localization of the normal Rauw fault in sandy Pliocene sediments with little lithological contrast (Verbeeck et al., 2017). A: classic CPT diagram representation, B: CPT derived $\mathrm{k}_{\mathrm{SBTn}}$ and non-normalized and normalized $\mathrm{I}_{\mathrm{c}}$ logs based on the same CPT's. The latter showing much higher log-response consistancy enabling the exact location of the fault. 
On a highly polluted formal industrial site in an alluvial sediment setting a lithological map of the subsoil was needed to evaluate the possible clean-up methods.

Because boreholes and pump tests were not allowed, CPTs with electric cones were chosen because of their fast execution time and small diameter to minimize cross contamination. Some tests made use of a pore water pressure cone for dissipation tests to determine hydraulic conductivity in the different lithologies and for comparison with the k-results obtained with the direct I derived method (Robertson, 2010b method; see also section 2.3).

Figure 12 shows a section throughout the alluvial deposits of a river valley with rubble infills cut into moderately compact Mesozoic chalk.

The positive experience with the CPT-derived $\mathrm{k}_{\mathrm{SBTn}}$ (and I) parameters, discussed in the previous sections, was the reason why in this exploration the same parameters were determined. They were visualized in a profile and interpolated between the CPTs by a triangulation method.

Because of the large lithologic contrasts present in the subsoil of the site, a good first view is obtained of the occurrence and extent of the permeable and impermeable layers throughout the section.

It has also be demonstrated that the $I_{c}$ proves to be a very appropriate parameter for computational and model based methods to establish stratigraphy and mapping based on large CPT datasets (e.g. Rogiers et al., 2012; Rogiers et al., 2017; Ching et al., 2015).

\subsubsection{Heist-op-den-Berg hill}

Verhaegen et al. (2020, this volume) discuss the stratigraphy and paleogeography of the Kasterlee Formation (c-K1 unit; see sections 3.1.3 and 3.1.4) based on a detailed granulometric and mineralogical study from new outcrops at the Heist-op-denBerg hill (Figs $1 \& 10$ ). As explained, because of poor evidence, this unit was not indicated on the geological map revision of the Flemish region (Schiltz et al., 1993). Later on, Fobe (1995) provided evidence for the presence of the Kasterlee Formation from outcrops at Heist-op-den-Berg and the nearby Beerzel hill.

Following the consistent results for local stratigraphy correlation based on the CPT derived parameters at the ONDRAF/NIRAS study area, where the clayey Kasterlee unit c-K1 was clearly defined, it was decided to execute some CPTs (WD-14-20140701-Sa and WD-14-20140701-Sb) as close to the hill tops as possible and perform a similar $\mathrm{I}_{\mathrm{c}}$ and $\mathrm{k}_{\mathrm{SBTn}} \log$ analysis. The results match well Fobe's (1995) observations and the $\log$ responses for this unit in at least the west part of the ONDRAF/NIRAS study area (Schiltz, 2015; Verhaegen et al., 2020 , this volume).

The $\log$ trends of $\mathrm{I}_{\mathrm{c}}$ and $\mathrm{k}_{\mathrm{SBTn}}$ are practically identical to the $32 \mu \mathrm{m}$ boundary in the granulometric log in Verhaegen et al. (2020, this volume). The $\mathrm{I}_{\mathrm{c}}$ and $\mathrm{k}_{\mathrm{SBTn}}$ represent as such a very accurate measure for indicative granulometric characteristics (Robertson, 2016).

The good analogy between both features is probably the result of the high-resolution sample interval $(30 \mathrm{~cm}$ for the granulometric analysis and $2 \mathrm{~cm}$ for the CPT measurements), well outperforming the $200 \mathrm{~cm}$ sample interval of the boreholes of the ONDRAF/NIRAS area (Figs 4, $5 \& 6$ ).

This confirms that both CPT-derived parameters not only can be used for stratigraphic and lithologic correlation but also for interpreting sedimentological trends (upward coarsening, fining...) from log response trends and signature (see Fig. 3).

\section{Conclusions and recommendations}

In this paper we examined how the CPTs available to the author from the ONDRAF/NIRAS project could be used in an optimal way for lithostratigraphic analysis.

A consistent analogy of CPT derived soil behavior index I and of hydraulic conductivity $\mathrm{k}_{\mathrm{SBTn}} \operatorname{logs}$ with GR borehole $\operatorname{logs}$ is observed from the correlation between six cored and logged boreholes and CPTs in the geological Neogene setting of the ONDRAF/NIRAS study area in NE Belgium.

As a versatile, fast and cost effective field investigation method, this feature improves the use of CPT's for soil profiling and stratigraphical analysis considerably, especially in a sandy geological setting with poor macroscopic lithologic contrast.

The availability of a large number of CPTs and their highsample resolution makes them highly effective to interpolate between other, more expensive field investigation methods. CPT derived lithology and permeability can be interpolated easily between CPT positions to obtain continuous images of the subsoil.

The advantage of the larger number of CPTs and smaller distances between them, combined with the observed CPTderived log features, makes it possible to propose boundaries and stratigraphic correlations offering a better spatial resolution and reliability.

In analogy with the use of GR logs for stratigraphic interpretation, the trends in the CPT derived logs can be used for sedimentological interpretations such as cycles and coarsening or fining up sequences, trends and log shapes to define and correlate subdivisions between CPTs.

The comparison of CPT based subdivisions with the complex stratigraphy, based on GR-RES logs, sedimentological data, and visual inspection of cores demonstrates that not only the CPT divisions closely reflect the stratigraphy but that they also can contribute to refine the stratigraphy of the ONDRAF/ NIRAS study area.

A particular stratigraphic contribution from CPT data is the extension of the 'clayey Kasterlee' unit into the stratotype area of the Kasterlee Formation and the similarity between the 'lower Mol' or 'Kasterlee sensu Gulinck' unit and the Kasterlee Sand in

S

cpretis

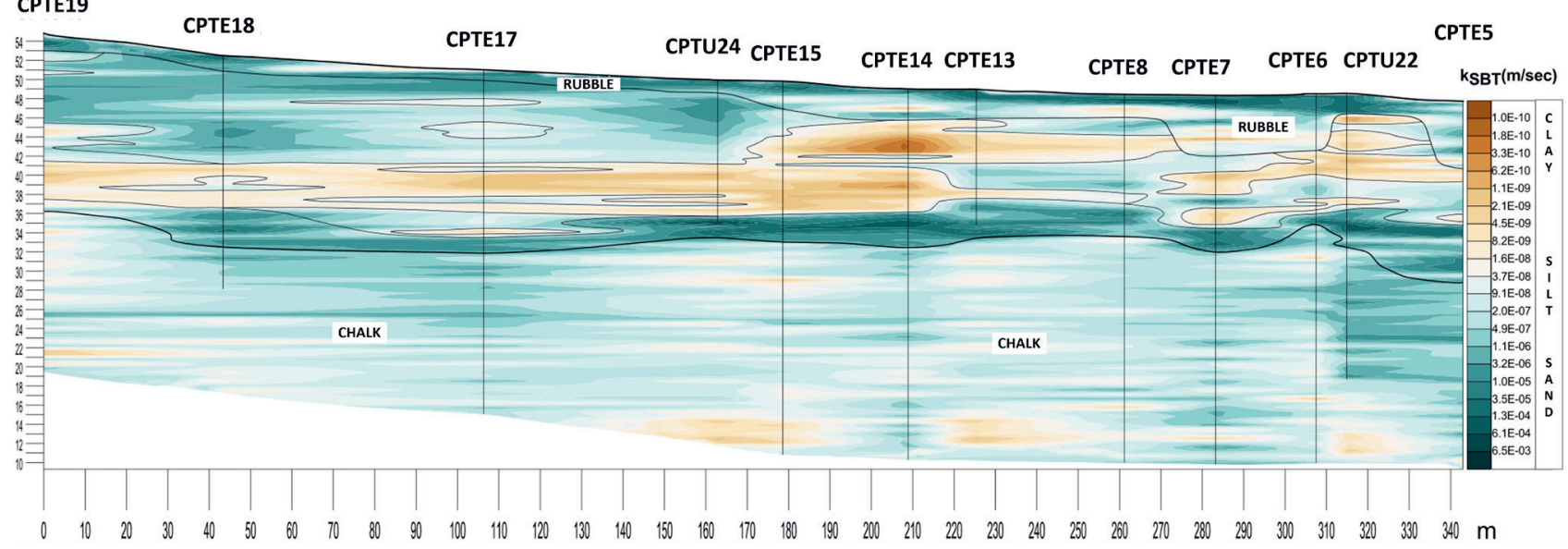

Figure 12. Section of static CPT's with electric cone through a river valley cut in Cretaceous chalk and filled with Quaternary heterogeneous sediments. The section visualizes variations of $\mathrm{k}_{\mathrm{SBTn}}$ (Robertson, 2010b) obtained by triangulation between CPT's, representing clayey (impermeable) and gravelly (permeable) zones. 
the stratotype area. Also the suggested possible extension of the Poederlee Formation beyond the Lichtaart-Kasterlee hill merits further investigation.

A detailed granulometric study at the Heist-op-den-Berg hill based on closely spaced samples confirms that CPT-derived log features can also be used to define sedimentary sequences.

This opens opportunities to further improve the local stratigraphic framework of the ONDRAF/NIRAS project site.

\section{Acknowledgements}

Special thanks to Professor Noël Vandenberghe for the opportunity to present this paper and for reviewing and discussing previous versions of the paper, improving its quality. Thanks also to Rik Houthuys and Jasper Verhaegen for prereviewing the paper and for their advices, and to the reviewers Henk van der Graaf, Gauthier Van Alboom and an anonymous reviewer for their constructive remarks. ONDRAF/NIRAS is thanked for making the dataset of CPTs available for processing.

\section{References}

Adriaens, R., 2015. Neogene and Quaternary clay minerals in the southern North Sea. Unpublished Ph.D. Thesis, KULeuven, Leuven, 272 p.

Adriaens, R. \& Vandenberghe, N., 2020. Quantitative clay mineralogy as a tool for lithostratigraphy of Neogene Formations in Belgium: a reconnaissance study. Geologica Belgica, 23/3-4, this volume. https://doi.org/10.20341/gb.2020.018

Beerten, K., Wemaere, I., Gedeon, M., Labat, S., Rogiers, B., Mallants, D. \& Salah, S., 2010. Geological, hydrogeological and hydrological data for the Dessel disposal site. Project near surface disposal of category A waste at Dessel. STB-SIE(HYD) - Version 1. NIRONDTR 2009-05 E. ONDRAF-NIRAS, Brussels, 259 p.

Ching, J., Wang, J.S., Juang, C.H. \& Ku, C.S., 2015. Cone penetration test (CPT)-based stratigraphic profiling using the wavelet transform modulus maxima method. Canadian Geotechnical Journal, 52/12, 1993-2007. https://doi.org/10.1139/cgj-2015-0027

Deckers, J., Van Noten, K., Schiltz, M., Lecocq, T. \& Vanneste, K., 2018. Integrated study on the topographic and shallow subsurface expression of the Grote Brogel Fault at the boundary of the Roer Valley Graben, Belgium. Tectonophysics, 722, 486-506. https:// doi.org/10.1016/j.tecto.2017.11.019

Douglas, B.J. \& Olsen, R.S., 1981. Soil classification using electric cone penetrometer. Proceedings of Conference on Cone Penetration Testing and Experience, St. Louis, 26-30 October 1981, 209-227.

DOV, 2020. Databank Ondergrond Vlaanderen [Flanders Soil and Subsurface Database]. https://www.dov.vlaanderen.be, accessed 20/04/2020.

Emery, D. \& Myers, K.J. (eds), 1996. Sequence Stratigraphy. Blackwell, Oxford, $297 \mathrm{p}$.

Gulinck, M., 1960. Un gisement de kiezeloolithes à Lichtaart (Campine). Comparaison avec le cailloutis à kiezeloolithes des collines flamandes. Bulletin de la Société belge de Géologie, de Paléontologie et d'Hydrologie, 69, 191-210.

Gullentops, F., 1963. Etude de divers faciès quaternaires et tertiaires dans le Nord et l'Est de la Belgique. Excursion O-P, 6e Congrès International de Sédimentologie 1963, Belgique et Pays-Bas, 20 p.

Gullentops, F. \& Vandenberghe, N., 1995. Toelichtingen bij de geologische kaart van België, Vlaams Gewest: kaartblad 17, Mol [1/50 000]. Belgische Geologische Dienst en Ministerie van de Vlaamse Gemeenschap, Afdeling Natuurlijke Rijkdommen en Energie, Brussel, 65 p.

Krassay, A.A., 1998. Outcrop and drill core gamma-ray logging integrated with sequence stratigraphy: examples from Proterozoic sedimentary successions of northern Australia. AGSO Journal of Australian Geology \& Geophysics, 17, 285-299.

Louwye, S., De Schepper, S., Laga, P. \& Vandenberghe, N., 2007. The Upper Miocene of the southern North Sea Basin (northern Belgium): a palaeoenvironmental and stratigraphical reconstruction using dinoflagellate cysts. Geological Magazine, 144, 33-52. https://doi. org/10.1017/S0016756806002627

Lunne, T., Robertson, P.K. \& Powell, J.J.M., 1997. Cone penetration testing in geotechnical practice. Blackie Academic, EF Spon/ Routledge Publishing, New York, 312 p.
NEN 5140, 1996. Nederlandse norm - Geotechniek. Bepaling van de conusweerstand en de plaatselijke wrijvingsweerstand van grond. Elektrische sondeermethode. Nederlands Normalisatie-instituut, Delft, 6 p.

Rider, M.H., 1999. The Geological Interpretation of Well Logs. Gardners Books, Eastbourne, 288 p.

Robertson, P.K., 1990. Soil classification using the cone penetration test. Canadian Geotechnical Journal, 27/1, 151-158. https://doi. org/10.1139/t90-014

Robertson, P.K., 2009. Interpretation of cone penetration tests - a unified approach. Canadian Geotechnical Journal, 46/11, $1337-$ 1355. https://doi.org/10.1139/T09-065

Robertson, P.K., 2010a. Soil behaviour type from the CPT: an update. $2^{\text {nd }}$ International Symposium on Cone Penetration Testing, Huntington Beach, CA, USA. Vol. 2, 575-583.

Robertson, P.K., 2010b. Estimating in-situ soil permeability from CPT and CPTu. $2^{\text {nd }}$ International Symposium on Cone Penetration Testing, Huntington Beach, CA, USA. Vol. 2, 535-542.

Robertson, P.K., 2016. Cone penetration test (CPT)-based soil behaviour type (SBT) classification system - an update. Canadian Geotechnical Journal, 53/12, 1910-1927. https://doi.org/10.1139/ cgj-2016-0044

Robertson, P.K., Campanella, R.G., Gillespie, D. \& Greig, J., 1986. Use of piezometer cone data. Proceedings of American Society of Civil Engineers, ASCE, IN-SITU '86 ASCE Specialty Conference on Use of In-situ Testing in Geotechnical Engineering, Blacksburg, 23-25 June 1986, 1263-1280.

Rogiers, B., Schiltz, M., Beerten, K., Gedeon, M., Mallants, D., Batelaan, O., Dessargeus, A. \& Huysmans, M., 2010. Groundwater model parameter identification using a combination of cone-penetration tests and borehole data. IAHR International Groundwater Symposium Proceedings, Vol. 1. Valencia, Spain, 19 p.

Rogiers, B., Mallants, D., Batelaan, O., Gedeon, M., Huysmans, M. \& Dassargues, A., 2012. The usefulness of CPTs for deterministic spatially heterogeneous, large-scale aquitard parameterisation. In Oswald, S.E., Kolditz, O., Attinger, S., (eds), Models - Repositories of Knowledge. Proceedings ModelCare 2011, Leipzig, Germany, 18-22 September 2011. IAHS Publication, 355, 41-47.

Rogiers, B., Mallants, D., Batelaan, O., Gedeon, M., Huysmans, M. \& Dassargues, A., 2017. Model-based classification of CPT data and automated lithostratigraphic mapping for high-resolution characterization of a heterogeneous sedimentary aquifer. PLoS ONE 12/5, e0176656. https://doi.org/10.1371/journal.pone.017665

Schiltz, M., 2008. Lithological and stratigraphical interpretation by means of cone penetration tests (CPT's) in the Dessel-KasterleeGeel-Mol area. Unpublished report. Bvba SAMSUFFIT Geoservices, NIRAS Fieldsurvey cAt 2008, 46 p.

Schiltz, M., 2011. Kasterlee. Problematiek relatie Formaties van MolPoederlee-Kasterlee. Verslag $n^{\circ}$ 20111123. Unpublished report. Samsuffit Geoservices, 15 p.

Schiltz, M., 2015. CPT-proeven en hun lithostratigrafische interpretatie; G3D Workshop G3Dv3 Neogeen -30-11-2015 VITO/ALBON

Schiltz, M., Vandenberghe, N. \& Gullentops, F., 1993. Toelichtingen bij de geologische kaart van België, Vlaams Gewest: kaartblad 16, Lier [1/50 000]. Belgische Geologische Dienst en Ministerie van de Vlaamse Gemeenschap, Bestuur Natuurlijke Rijkdommen en Energie, Brussel, 38 p.

Searle, I.W., 1979. The interpretation of Begemann friction jacket cone results to give soil types and design parameters. Proceedings of the $7^{\text {th }}$ European Conference on Soil Mechanics and Foundation Engineering, ECSMFE, Brighton, Vol. 2, 265-270.

SEPM Strata, 2015. Well Log Interpretations, Character of Log Response. http://sepmstrata.org/page.aspx?\&pageid=168\&3, accessed 19/03/2020.

Vandenberghe, N., Wouters, L., Schiltz, M., Beerten, K., Berwouts, I., Vos, K., Houthuys, R., Deckers, J., Louwye, S., Laga, P., Verhaegen, J., Adriaens, R. \& Dusar, M., 2020. The Kasterlee Formation and its relation with the Diest and Mol Formations in the Belgian Campine. Geologica Belgica, 23, 3-4, this volume. https://doi.org/10.20341/ gb. 2020.014

Verbeeck, K., Wouters, L., Vanneste, K., Camelbeeck, T., Vandenberghe, D., Beerten, K., Rogiers, B., Schiltz, M., Burow, C., Mees, F., De Grave, J. \& Vandenberghe, N., 2017. Episodic activity of a dormant fault in tectonically stable Europe: The Rauw fault (NE Belgium). Tectonophysics, 699, 146-163. https://doi.org/10.1016/j. tecto.2017.01.023 
Verhaegen, J., Adriaens, R., Louwye, S., Vandenberghe, N. \& Vos, K., 2014. Sediment-petrological study supporting the presence of the Kasterlee Formation in the Heist-op-den-Berg and Beerzel hills, southern Antwerp Campine, Belgium. Geologica Belgica, 17, 323 332.

Verhaegen, J., Frederickx, L. \& Schiltz, M., 2020. New insights into the stratigraphy and paleogeography of the Messinian Kasterlee Formation from the analysis of a temporary outcrop. Geologica Belgica, 23, 3-4, this volume. https://doi.org/10.20341/gb.2020.015

VPO (Vlaams Planbureau voor Omgeving), 2019. Stratigrafische tabel voor het Neogeen en Paleogeen van Vlaanderen. Databank Ondergrond Vlaanderen, https://dov.vlaanderen.be/sites/default/ files/pfiles_files/StratigrafischeTabel_NeogeenPaleogeen DOV2019 2.pdf, accessed 20/04/2020.

Wouters, L. \& Schiltz, M., 2013. Overview of the field investigations in and around the nuclear site of Mol-Dessel. Project near surface disposal of category A waste at Dessel. Version 1 - NIROND-TR 2011-42 E, 109 p.

Manuscript received 24.03.2020, accepted in revised form 09.06.2020, available online 08.09.2020 